\title{
Soil Bio-Impact Effectiveness for the Optimal Multicriterial Environmental Sustainability in Crop Production
}

\author{
Vilma Naujokienè ${ }^{1, *(\mathbb{D})}$, Daiva Rimkuviene ${ }^{2}$ and Egidijus Šarauskis ${ }^{1}$ (D) \\ 1 Institute of Agricultural Engineering and Safety, Vytautas Magnus University, 44248 Kaunas, Lithuania; \\ egidijus.sarauskis@vdu.lt \\ 2 Department of Applied Informatics, Vytautas Magnus University, 44248 Kaunas, Lithuania; \\ daiva.rimkuviene@vdu.lt \\ * Correspondence: vilma.naujokiene@vdu.lt; Tel.: +370-673-58-114
}

Citation: Naujokienè, V.; Rimkuvienè, D.; Šarauskis, E. Soil Bio-Impact Effectiveness for the Optimal Multicriterial Environmental Sustainability in Crop Production. Agronomy 2021, 11, 72. https://doi. org/10.3390/agronomy11010072

Received: 24 November 2020 Accepted: 25 December 2020 Published: 31 December 2020

Publisher's Note: MDPI stays neutral with regard to jurisdictional clai$\mathrm{ms}$ in published maps and institutional affiliations.

Copyright: () 2020 by the authors. Licensee MDPI, Basel, Switzerland. This article is an open access article distributed under the terms and conditions of the Creative Commons Attribution (CC BY) license (https:// creativecommons.org/licenses/by/ $4.0 /)$.

\begin{abstract}
Different bio-impacts affect the various properties and composition of soil, plant residues, harvests, and technological processes, as well as the interactions between different parts of the soil, working machine tools, energy consumption and environmental pollution with harmful gases. To summarize the wide-coverage investigations of various aspects of different bio-impact parameters, a multicriteria evaluation was conducted. Experimental research shows that different bioeffects such as those of agricultural practices can be oriented towards a reduction in fuel consumption, followed by reductions in $\mathrm{CO}_{2}$ emissions from machinery and changes in soil properties, dynamics of composition, yield and other parameters. A multicriteria assessment of the essential parameters would give farmers new opportunities to choose one optimal decision for reducing fuel consumption and increasing agricultural production, thereby reducing the negative environmental impact of soil cultivation processes, increasing yields and improving soil. Of all the properties investigated, from a practical point of view, the selection of the most important of all the essential links, such as reducing energy and expenditure, reducing environmental pollution, improving soil, and increasing yields and productivity, is reasonable. The evaluation of the bio-impact effects in agriculture by accounting for many criteria from several aspects was the main objective of the multicriteria assessment using the analytic hierarchy process. Based on the results of a multivariable research of fuel consumption- $\mathrm{C} 1$, $\mathrm{C} 2$, yield- $\mathrm{C} 3, \mathrm{CO}_{2}$ from soil- $\mathrm{C} 4$, density- $\mathrm{C} 5$, total porosity- $\mathrm{C} 6$, humus $-\mathrm{C} 7$, soil stability- $\mathrm{C}$, and soil moisture content- $\mathrm{C} 9$, the evaluation used experimental research data and the Simple Additive Weighting (SAW) mathematical method to find the best-case scenario. Multicriteria effectiveness was most pronounced after the first and third soil bio-impacts by using a solution of essential oils of plants, 40 species of various herbs extracts, marine algae extracts, mineral oils, Azospirillum sp. (N), Frateuria aurentia $(K)$, Bacillus megaterium $(P)$, seaweed extract. The most important goal was to achieve the best soil bio-impact effectiveness—-minimized energy consumption from ploughing and disc harrowing operations, parallelly minimized harmful emissions from agricultural machinery, minimized $\mathrm{CO}_{2}$ from soil, soil density, maximized soil total porosity, soil humus, soil stability, yield and optimized soil moisture.
\end{abstract}

Keywords: bio-impact effect; multicriteria; fuel consumption; soil properties; best-case scenario

\section{Introduction}

There is much specialized research into the influence of different bio-impacts on the various parameters of plants, soil, germination energy, fungal infection, ecological winter wheat seeds.

In agricultural practice, bio-impact is used for biological protection of plants (reducing the spread of pathogens and pests) in order to increase the productivity of the crops, improve the microbiological state of the soil, change the physical or chemical properties of the soil [1,2]. Organic colloids have been found to be formed using soil biomass (soil 
temperature $\left( \pm 2{ }^{\circ} \mathrm{C}\right)$ changes), resulting in higher seed germination, maximizing yields [3]. Scientists have used different bio-impacts to determine their effectiveness for different purposes. Other scientists analyzed free live nitrogen-fixing bacteria by using plant residues and by studying their mechanical properties [4], using different techniques for checking the mechanical properties of plant residues. Scientists analyzed strains of Trichoderma used in crop-plant production as plant growth promoters and biological control agents. Strains were applied as biomeasurements to the soil in open-field lettuce cultivation, and their population levels were monitored over time. A multiplex-PCR Trichoderma-identification technique was used to confirm the increased abundance of T. atroviride and T. harzianum in the soil as a strategy to decrease pesticide use that utilized beneficial microorganisms. Other scientific analysis showed that different Trichoderma lineages exerted their beneficial effects for separate biocontrol-related mechanisms $[5,6]$.

Active development of biomethods resulted, continuously increasing numbers of all technological processes implemented using microorganisms. It could be an alternative for the chemical usage operations which pose hazards to the environment $[7,8]$.

The soil with the help of biopreparation with such components as earthworms E. fetida in the presence of bacteria Pseudomonas, nitrogen-fixing bacteria Azotobacter and Clostridium, yeasts Saccharomyces, Aspergillus and Penicillium fungi, as well as Actinomycetales showed that in petroleum-contaminated soil with $20-60 \mathrm{~g} \mathrm{~kg}^{-1}$ of petroleum the content of hydrocarbons decreased by $99 \%$ after 22 weeks in the presence of worms and bio-impact [9]. According to other scientists, chitosan nanoparticle-treated chickpea seeds have shown positive morphological effects such as enhanced germination, seed vigor index and vegetative biomass of seedlings and chitosan nanoparticles can be further used under field conditions to protect various crops from destructive germ cell pathogens as well as growth promoters [10]. Scientific results also showed that biocrusts significantly improved soil physicochemical properties, basal respiration and soil alkaline phosphatase, protease and cellulose, and decreased $\mathrm{CO}_{2}$ in vegetated areas [11]. Organic farming increased soil organic matter content, soil water content, and the abundance of both endogenic and epigenic earthworm species. Non-inversion tillage increased crop yield, soil organic matter content, and soil penetration resistance. The goal is an innovative application of a bio-method, in which, together with chemistry, biological processes can be regulated when biopreparations are incorporated into the soil, considering not only the effects on plants but also the soil microbiocenosis. It was established that the application of nitrogen fertilizers does not affect the net energy coke but reduces energy efficiency and significantly increases GHG emissions. By transforming nitrogen, microorganisms of different physiological groups cause important processes in the soil such as ammonification and immobilization of mineral nitrogen. Therefore, the modification of mineral fertilizers with nutrients $(\mathrm{N}, \mathrm{P}, \mathrm{K})$, biopreparations and organic waste can maintain or increase the organic carbon content of the soil, thereby increasing porosity and reducing the energy consumption of soil cultivation and the effects on global warming of synthetic fertilizers [12].

During soil tillage technological processes, the main changes occur in the upper soil layer-the soil is mixed with inorganic or organic fertilizers and plant residues. In order to cultivate soil by inserting plant residues, ground and surface soil cultivation are applied, but the main problem is environment polluted with harmful gases, high energy and fuel consumption. So far, it has not been established whether soil properties change the energy costs of agricultural machinery and reduce the amount of carbon dioxide emissions from agricultural machinery.

Correct decision-making is a very difficult task when many alternatives exist. Environmental engineering research is concerned with a lot of different situations with complex problems. The determination of the balance among all components and making the right decision in a multilevel situation becomes complicated. The usage algorithms for multicriteria decision analysis (MCDA) could formalize and break down all aspects of the process. The importance is the selection of suitable materials and process selection and optimiza- 
tion. Also assessed whether MCDA techniques could be used in analytical chemistry for complexing decision-making processes [13].

Agriculture is affected by a variety of parameters such as the soil, the weather conditions, different technologies opportunities. Assessment of the variability of these factors could be compared by multicriteria analysis by classification into three different groups [14]. It was established that multicriteria accounting can help farmers and the policy makers for sustainable agricultural production control ensuring access to safe, healthy food production [15].

Climate change concentrated on global environmental issues and nations must achieve zero global $\mathrm{CO}_{2}$ gain [16], with particular emphasis on public awareness and education with the need to adapt to new developments [17]. Another assessment concluded that climate change requires a reduction in the use of fossil fuels and a shift towards a lowcarbon production technology [18]. According to the large demand for global production and grain yields, by impacting a lot of environmental categories the main domains for the oilseed crop are determined based on rapeseed and wheat as a main source of food. Wheat accounts for $70-90 \%$ of the total caloric intake and $66-90 \%$ of the protein intake $[19,20]$.

With the abstraction of a wide range of experimental research, a mathematical multicriteria analysis of bio-impacts could be performed. Numerous methods could be developed for ranking alternatives in stages: identification of alternatives to be compared, definition of the evaluation criteria, the characterization of alternatives, the determination of the weight of the preferences or the importance of every indicator [21]. The combination of multidirectional information into one value became very important for comparing different alternatives. Multicriteria consolidation could be used for combination of all goals into a single, readily understandable numerical value and like multifunctional optimization at the selection phase [22,23].

According to abstractions from various research it has been highlighted that it is relevant to perform multicriteria evaluation for the best practical effect of bio-impact in agriculture. The soil bio-impact of agricultural practices can be geared towards reducing fuel consumption and harmful $\mathrm{CO}_{2}$ emissions from machinery, depending on the soil properties improving, and increasing the harvest and causing other changes in parameters.

The main objective - to identify the best-case scenario of soil bio-impact effect for optimal multicriterial environmental sustainability in crop production.

\section{Materials and Methods}

Estimation of control (SC1) and different bio-impact scenarios (SC2-SC8) were performed in deep, lukewarm soaked soil fields (Endohypogleyic-Eutric Planosol_PLe-gln-w) at the Vytautas Magnus University experimental station, located at the southwest side of Kaunas city, on the left side of the Nemunas river $\left(54^{\circ} 534^{\prime} \mathrm{N}+23^{\circ} 50^{\prime} \mathrm{E}\right)$, where the average of soil $\mathrm{pH}-6.5-7.2$ (measured in $1 \mathrm{~mol} / \mathrm{L} \mathrm{KCl}$ suspension-LST ISO 10390: 2005), total nitrogen-1.47-1.59\%, humus 2.2-3.0\%, mobile phosphorus $0.173-0.235 \mathrm{~g} \mathrm{~kg}^{-1}$, mobile potassium - $0.115-0.189 \mathrm{~g} \mathrm{~kg}^{-1}$, mobile sulfate- $0.0056-0.264 \mathrm{~g} \mathrm{~kg}^{-1}$. In spring, when the vegetation of plants is renewed, winter wheat (in the first and second year) and oilseed rape (in the third year) culture grown in the same fields affected by seven types of different biosolutions from SC2 to SC8 scenario, which consist of water, essential oil, extracts of various grasses, extracts of sea algae, mineral oils, Azospirillum sp., Frateuriaurenticus, Bacillus megaterium, Azotobacterchroococcum, Azospirillumbrasilense, phosphorus, potassium, Azotobacter vinelandii, humic acids, gibberellic acid, copper, zinc, manganese, iron, calcium (spray rate 1.0 to $4.0 \mathrm{~L} \mathrm{ha}^{-1}$ (components BT1 spreading rate- $4 \mathrm{~L} \mathrm{ha}^{-1}$, BT2 spreading rate $-2 \mathrm{~L} \mathrm{ha}^{-1}, \mathrm{BT} 3$ spreading rate $-1 \mathrm{~L} \mathrm{ha}^{-1}, \mathrm{BT} 4$ spreading rate $-1 \mathrm{~L} \mathrm{ha}^{-1}$ ) by mixing with $200 \mathrm{~L}$ of water) (Table 1, Figure 1) [24]. 
Table 1. Different scenarios of soil bio-impact.

\begin{tabular}{|c|c|c|c|c|c|c|c|c|}
\hline Operations & Water Spraying & BT1 & BT2 & BT3 & BT4 & $\mathrm{BT} 1+\mathrm{BT} 2$ & BT1 + BT3 & BT1 + BT4 \\
\hline $\begin{array}{l}\text { Winter wheat "Ada" (the first } \\
\text { year)/"Famulus" (the second } \\
\text { year)/rapeseed "Cult" (the } \\
\text { third year) seeding }\end{array}$ & + & + & + & + & + & + & + & + \\
\hline Biopreparations spraying & - & + & + & + & + & + & + & + \\
\hline Control Scenario SC1 & + & - & - & - & - & - & - & - \\
\hline Biotreatment Scenario SC2 & - & + & - & - & - & - & - & - \\
\hline Biotreatment Scenario SC3 & & & + & - & - & - & - & - \\
\hline Biotreatment Scenario SC4 & - & - & - & + & - & - & - & - \\
\hline Biotreatment Scenario SC5 & - & - & - & - & + & - & - & - \\
\hline Biotreatment Scenario SC6 & - & - & - & - & - & + & - & - \\
\hline Biotreatment Scenario SC7 & - & - & - & - & - & - & + & - \\
\hline Biotreatment Scenario SC8 & - & - & - & - & - & - & - & + \\
\hline Harvest & + & + & + & + & + & + & + & + \\
\hline Disc harrowing & + & + & + & + & + & + & + & + \\
\hline Ploughing & + & + & + & + & + & + & + & + \\
\hline
\end{tabular}

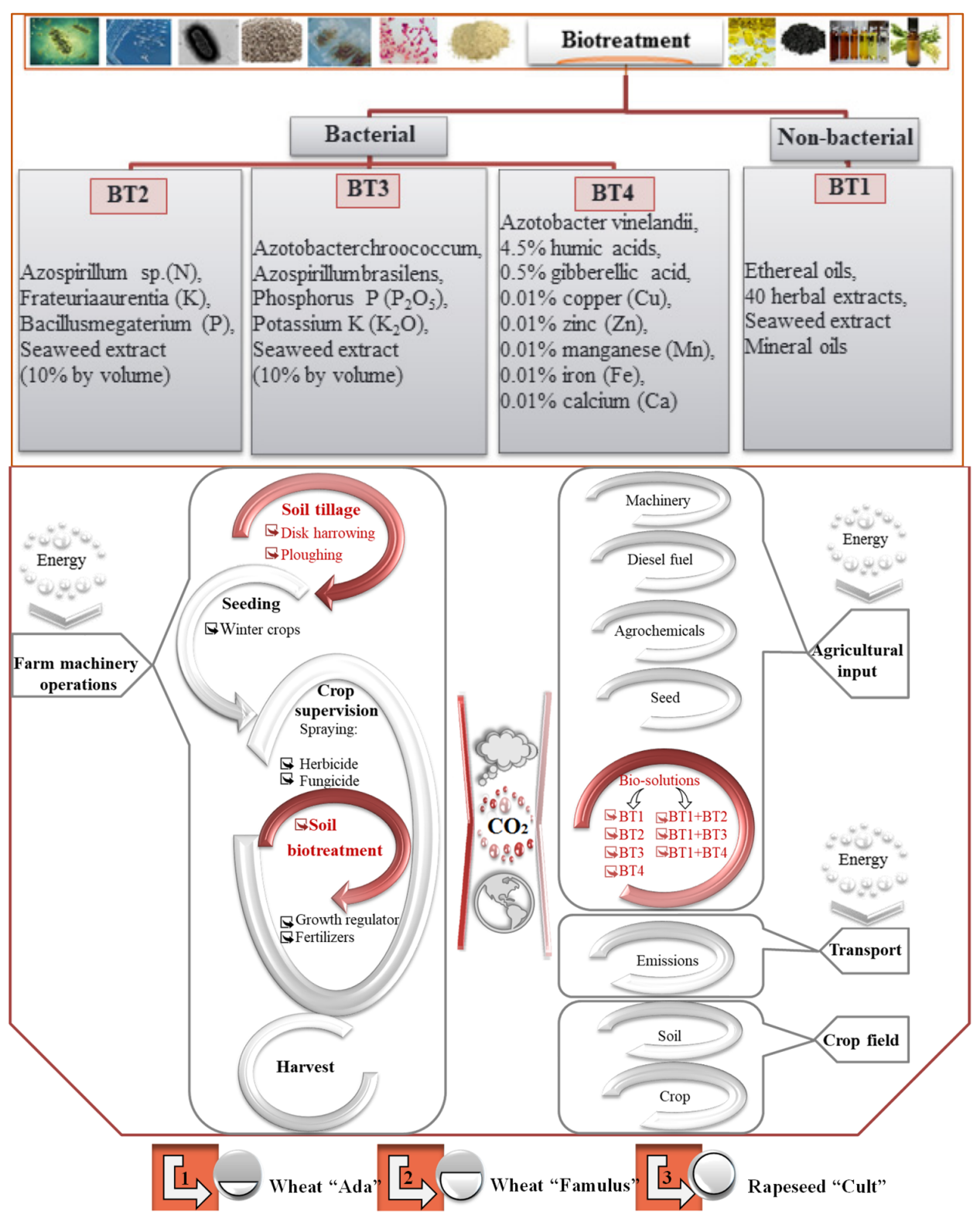

Figure 1. Experimental research design using bio-impact in crop production technology. 
The meteorological conditions during the experimental research — the average of daily temperature during the month was $20.3^{\circ} \mathrm{C}$, and the average precipitation was $6.9 \mathrm{~mm}$ in the first year (2015), accordingly was $16.90^{\circ} \mathrm{C}$ and $114.9 \mathrm{~mm}$ in the second year (2016), and $17.47^{\circ} \mathrm{C}$ and $55 \mathrm{~mm}$ in the third year (2017). The meteorological conditions were measured during the experimental research on the summer month of August, when the disc harrowing, ploughing and harvest technological operations took place. Meteorological conditions data from a meteorological station at this location were used.

Research was carried out on fuel consumption parameters of soil tillage machines, yield, soil density, total porosity, humus, soil stability, soil moisture content. About 1-2 h before soil tillage, soil properties were investigated. For research purposes, in each repetition using the soil drill were taken 20 combined soil samples from the $0-25 \mathrm{~cm}$ layer of soil. Each of five experimental research variant repetitions of measurement (length $50 \mathrm{~m}$, width $12 \mathrm{~m}$ ) was performed randomly in 4 divided $600 \mathrm{~m}^{2}$ areas in the middle of an average of $25 \mathrm{~m}$ from the beginning of the area in one side and the other side of the technological creeps. Soil humidity, temperature and electrical conductivity-electronic sensor and data logger Delta-T (HH2) with a probe WET Sensor type WET-1, its porosity-pycnometer Air Pycnometer, the soil gravity strength-field inspection vane tester, soil sampling-Wintex 1000 Automated Soil Sampling System Mounted on a quad bike Honda TRX 680Rincon with GPS equipment, soil structure (Savinov method)_analytical shaker with "Analytical sieve shaker AS 200 control Retsch.

The soil emissions were measured using a portable gas emission analyzer (ADC LCPro Plus). After analyzer calibration, probing nozzles mounted in a special hood, on each of five surfaces of differently affected soil variant (control, 1, 2, 3, 4 biosolutions and biosolution mixtures) without gaps, and the side effects of environmental factors. The data of the research was recorded $30 \mathrm{~s}$ after the device was placed on the soil measurement site and stored in the analyzer data collector with the purpose of performing analysis by computer. The evaluation used experimental research data and the SAW mathematical method to find the best-case scenario.

The selection of the relevant criteria and indicators was based on the received feedback of local experts from literature reviews, data availability and accessibility.

\subsection{Determination of the Weight of the Preferences and Optimality of Each Environmental Sustainability Criterion for Soil Bio-Impact Effect}

One of the most important steps was determining the weights of individual criteria so that all scenarios could be compared based on the aggregate performance of all criteria. In this case, the analytic hierarchy process (AHP) was the methodology chosen, which allows the conversion of subjective evaluations into numerical values. The AHP methodology compares criteria in a pairwise approach. The comparison between two elements using AHP can be accomplished in different ways. The relative importance scale of 1-9 between two alternatives as suggested by Saaty [25] is the most widely used. Aupetit and Genest [26] and Hossain et al. [27] proposed the use of a reduced scale of 1-5. The assigned quantitative value was determined from the specified scale $1-5$, where equal importance means-1 of numeric value, moderate importance means - 2 of numeric value, strong importance means -3 of numeric value, very strong importance means -4 of numeric value and extreme importance means -5 of numeric value.

For determination of the weight of the preferences, the pairwise comparison matrix (presuming that criterion 1 dominates over criterion 2) of the criteria was performed. In comparisons between elements at a given hierarchical level, the principal assumption is that an element on line $i$ is always compared with an element in column $j$. Thus, $a_{i j}$ indicates how much more important the $i$-th element is than the $j$-th element. If stated that the $i$-th element is, for instance, more important than the $j$-th element $\left(a_{i j}=\mathrm{x}\right)$, then, automatically, the assumption is that $\left(a_{j i}=1 / \mathrm{x}\right)$. The values in the diagonal of the matrix are always 1 , since when compared with itself, each criterion has equal importance. The 
main analyzed elements of a normalized comparison matrix were calculated according to the following formula:

$$
a_{i j}^{*}=\frac{a_{i j}}{\sum_{j} a_{i j}}
$$

That is, each value in the matrix is divided by the sum of its column.

$$
w_{i}=\frac{1}{n} \sum_{j} a_{i j}^{*}
$$

Finally, the criteria weight vector $w$ is built by averaging the entries in each row of the normalized matrix.

The experimental results indicated that the average values of the indicators were determined by dependence on the different scenarios, because by depending on the bioimpact, the density of the soil increased from 0.7 to $13 \%$, and the total porosity increased to $25 \%$, which had a significant impact on fuel consumption and $\mathrm{CO}_{2}$ emissions. Other soil characteristics were not included in the multicriteria assessment, as they were not considered appropriate, because research showed that (in the case of the analysis of the technology) properties such as soil temperature were significantly dependent on meteorological conditions or electrical conductivity of the soil had no significant effect. Soil moisture criteria was accepted as optimal concrete value. According to the findings of the experimental research, evaluation criteria and their types were chosen by the evaluation of alternatives (Table 2).

\begin{tabular}{|c|c|c|c|}
\hline Description of Criteria & Indicators Used & Code & Type of Criteria \\
\hline \multirow{2}{*}{ Energy consumption } & Fuel consumption from ploughing operation, $\mathrm{L} \mathrm{h}^{-1}$ & $\mathrm{C} 1$ & Less is better \\
\hline & Fuel consumption from disc harrowing operation, $\mathrm{L} \mathrm{h}^{-1}$ & $\mathrm{C} 2$ & Less is better \\
\hline \multirow[t]{3}{*}{ Productivity } & $\begin{array}{l}\text { Grain yield (Winter wheat "Ada" (the first year)/"Famulus" } \\
\text { (the second year)/rapeseed "Cult" (the third year), } \mathrm{t} \mathrm{ha}^{-1}\end{array}$ & $\mathrm{C} 3$ & More is better \\
\hline & $\mathrm{CO}_{2}$ from soil, $\mu \mathrm{mol} \mathrm{m} \mathrm{s}^{-1}$ & $\mathrm{C} 4$ & Less is better \\
\hline & Soil density $\mathrm{g} \mathrm{cm}^{-3}$ & $\mathrm{C} 5$ & Less is better \\
\hline \multirow{4}{*}{$\begin{array}{l}\text { Main influencing } \\
\text { soil parameters }\end{array}$} & Soil total porosity, $\%$ & C6 & More is better \\
\hline & Soil humus, $\%$ & $\mathrm{C} 7$ & More is better \\
\hline & Soil stability, \% & $\mathrm{C} 8$ & More is better \\
\hline & Soil moisture, $\%$ & C9 & Optimal 20\% \\
\hline
\end{tabular}

Table 2. Description and type of criteria (optimal and less or more is better) and indicators for the evaluation of alternatives.

Comparison matrix and multicriteria evaluation were done for all nine indicators separately. After a deeper analysis, however, equally important indicators for practitioners were grouped according to relevance. It was identified equally most important group indicators-fuel consumption from ploughing and disc harrowing operations, grain yield. It was identified an equally moderately important group indicators- $\mathrm{CO}_{2}$ from soil, soil density, soil total porosity. It was identified equally least important group indicators-soil humus, soil stability, soil moisture. All indicators divided into groups according to a tire area by description of criteria such as energy consumption, productivity, main influenced soil parameters.

Characterisation of alternatives was performed according to the indicators, such as the best scenario for individual indicators in the analyzed year, the indicator whose change in the survey year was the highest with respect to the partial target, and the trends of the variables analyzed.

The study was carried out by analyzing different bio-impact compositions and control by main indicators through three bio-impact seasons in 2015, 2016, and 2017 (Table 2).

Bio-impact effectiveness has been determined in comparison with the control variant. In predicting the variation of meteorological conditions in the different years of experimental research and the risk of crop rotation, only changes and differences were objectively 
highlighted compared to the control version of SC1 scenario in which the biopreparations were not used.

\subsection{Assessment of Optimal Multicriterial Environmental Sustainability in Crop Production}

The main goal of a multicriteria assessment is to rank scenarios from a multicriteria perspective accounting for several aspects. The best method selected for defining alternative priorities as a multicriteria technique is Simple Additive Weighting (SAW). The calculation algorithm of the method is not complicated and is easily understood by decision makers [28,29]. Moreover, Janssen R. [30] argues that although computationally simple, weighted summation often provides a reliable solution. This method clearly demonstrates the main concept of multicriteria evaluation methods - the integration of the criteria values and weights into a single magnitude [31].

The basic logic of the SAW method is to obtain a weighted sum of the performance ratings of each alternative over all attributes. The overall preference index $\left(P I_{j}\right)$ of each scenario $_{j}$ is obtained by the following formula:

$$
P I_{j}=\sum_{i-1}^{n} w_{i} z_{i j}^{*}
$$

All criteria can be classified into the following categories:

"more is better" - the higher value of the indicator is the higher subscore of the indicator too;

"less is better" - the lower value of the indicator is the higher subscore of the indicator too;

"optimum"- a limited range of values which corresponds to a high subscore, whereas the "less" and "more".

Thereby, it is necessary to reconstruct the indicators so that an increase in the normalized indicators corresponds to an increase in the preference index. Consequently, the normalization requires the additional transformation [32,33]:

$$
t_{i j}=\left\{\begin{array}{l}
z_{i j}, \text { if " more is better" } \\
\frac{1}{z_{i j}}, \text { if "less is better" }
\end{array}\right.
$$

By indicators which belong to the "optimum" category, two situations can be met, i.e., the observed value can be below or above the optimum value. Thus, the value is transformed into a new value using the following formula [34]:

$$
t_{i j}=\left\{\begin{array}{l}
\frac{z_{i j}}{z_{o p t}}, \text { if observed value was below the optimum } \\
\frac{z_{\text {opt }}}{z_{i j}}, \text { if observed value was above the optimum }
\end{array}\right.
$$

Based on available knowledge, each criterion may be measured in different units, but in the SAW method, it is necessary to normalize the decision matrix into a scale comparable to all alternatives. All indicators are normalized to obtain dimensionless classifications. As mentioned by [35], the best normalization technique for SAW is vector normalization. This method has the advantage of converting all attributes into a dimensionless measurement unit scale in the interval (0-1) as follows:

$$
z_{i j}^{*}=\frac{t_{i j}}{\sqrt[a]{\sum_{j} t_{i j}^{a}}}(\alpha>0)
$$

The final ranking of scenarios is determined based on the increasing value of the preference index. The best alternative is the one that obtains the highest value of $P I_{j}$. 


\subsection{Statistical Analysis}

In the characterisation of alternatives, the description of the mean values of the indicators was useful, as was the comparison and assessment of the nature of their changes. To determine whether the differences were statistically significant, ANOVA one-factor analysis and graphical analysis were applied (using the honest significant difference method between the averages of the data evaluation (HSD05) (probability level 95\%). Arithmetic averages, standard deviation, and their intervals of confidence were determined with probability level $p<0.05$. After evaluation of the accuracy of the experimental data, the calculated numerical values of the test accuracy revealed that the calculated data were very precise. The accuracy specified did not exceed $5 \%$ (with a numeric accuracy value of $p<0.05$ ).

\section{Results and discussion}

The results were evaluated on a year-by-year basis and the impact was assessed when crop rotation is applied, as is customary in practice for farmers (Figure 2).

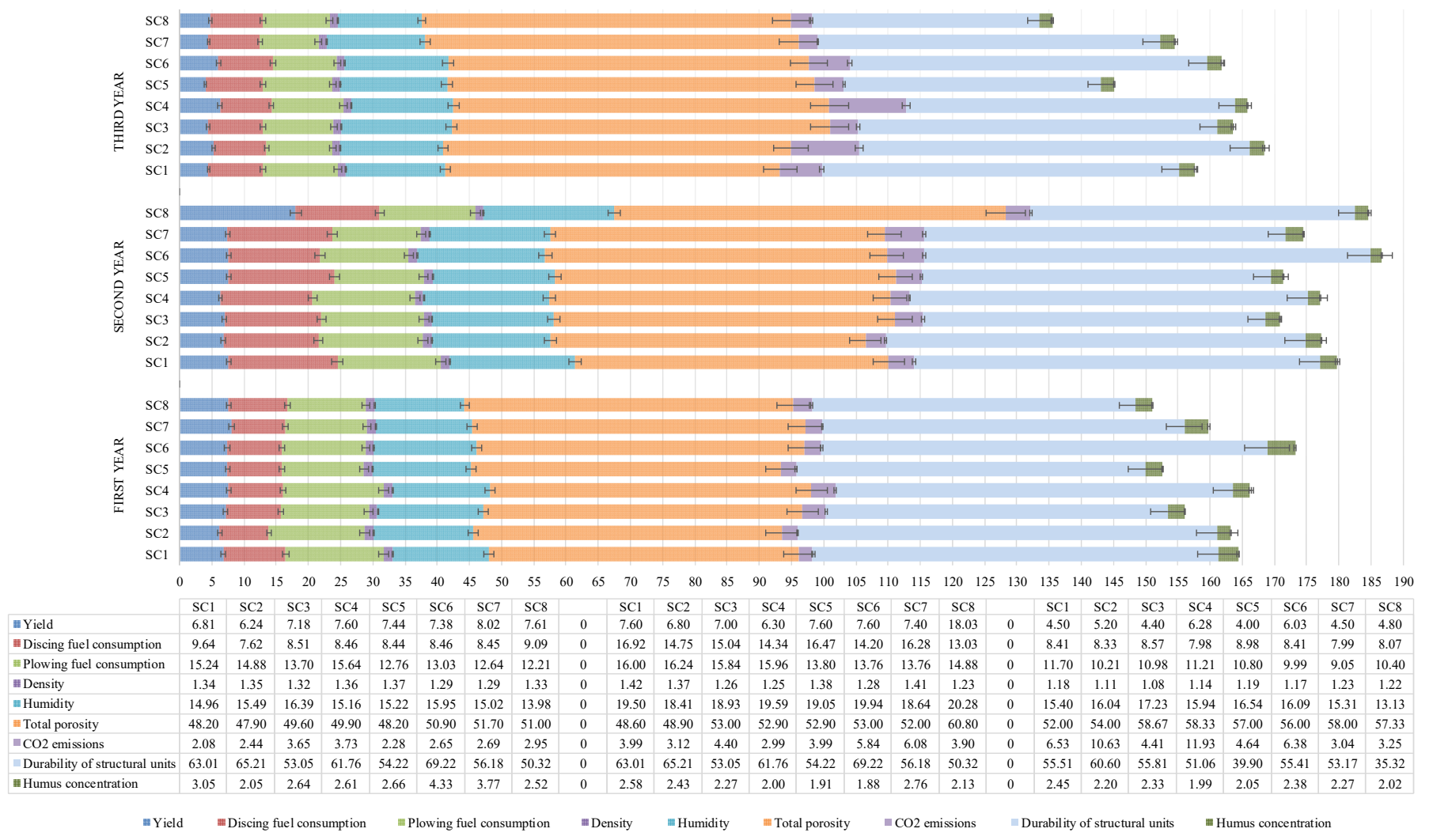

Figure 2. Different parameters of three years dependence on different bio-impact scenarios.

Different bio-impact effectiveness for the harvest were established as a change compared with control. Estimated that the increased yield due to biotreatment effect addictive increased income finances too. Six of all scenarios was effective in first year. In the overall assessment of all evaluated parameters depending on the different year and different bioimpact, the apparent change in significance in the second year. But the variation of different parameters in the first, second and third years was very different, so the significance of each bio-exposure parameter was further analyzed in more detail.

\subsection{Ploughing Fuel Consumption Dependence on Optimal Bio-Impact(s) Time (Year) and Scenario}

Comparing 2015 and 2017, fuel consumption from ploughing declined in all scenarios. Scenario SC8 had the least fuel consumed in 2015, SC6 and SC7 the least in 2016, and SC7 
the least in 2017. Fuel consumption was statistically significant both in terms of year, by scenario, and by year-scenario interaction $(p<0.01)$ (Figure 3$)$.

Up to $85 \%$ of all bio-impacts tested were effective in reducing the cost of deepcultivation fuels. The essential effect of using bio-impact in years 1,2 and 3 according to scenarios 5, 6, 7 and 8 in comparison with the control variant was determined.

Summarizing the results of deep soil cultivation research, the most effective scenario was founded: during the first year, use of bio-impact reduced fuel consumption to $19.2 \%$ and during the third year use of bio-impact reduced it to $23.5 \%$.

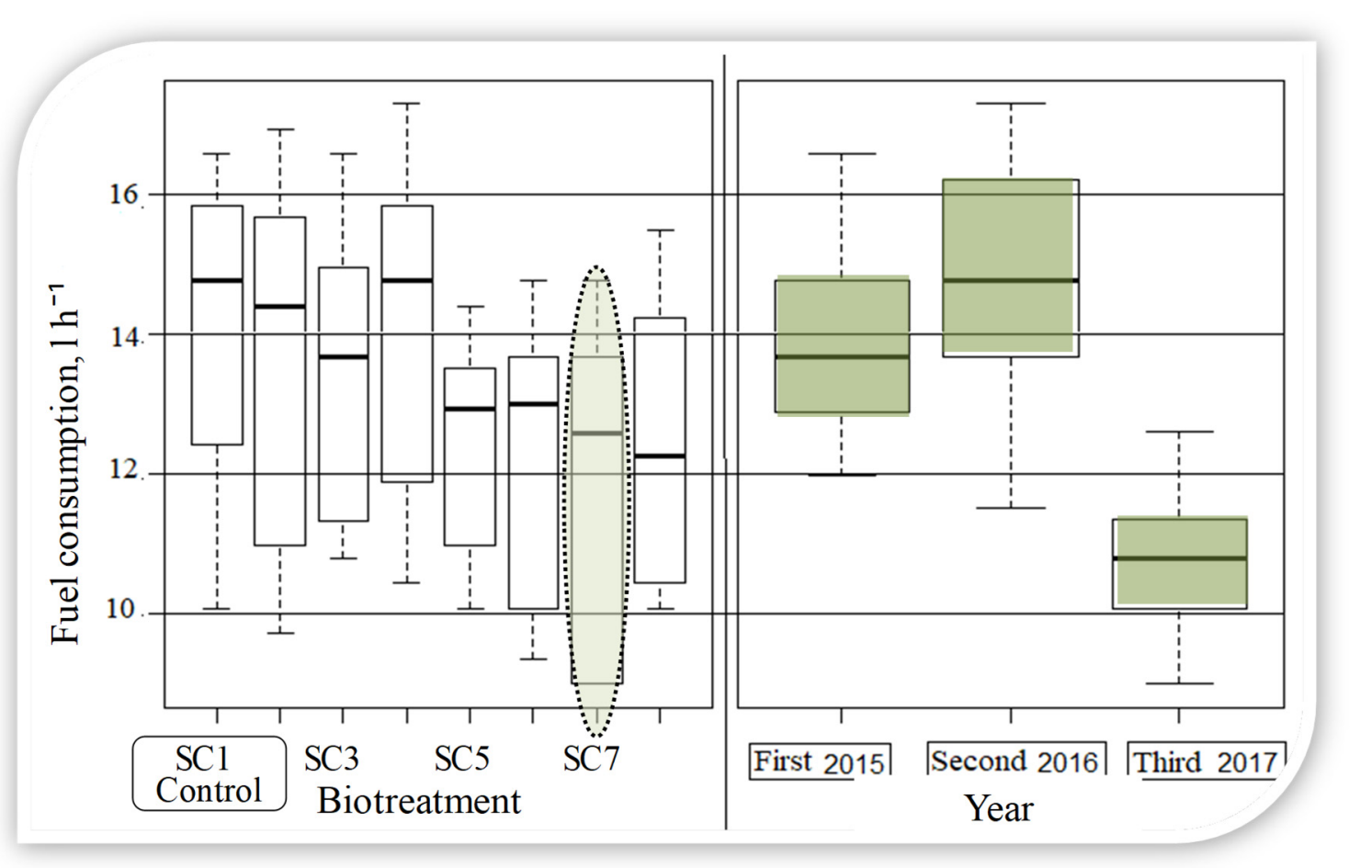

Figure 3. Ploughing fuel consumption $\left(\mathrm{L} \mathrm{h}^{-1}\right)$ dependence on bio-impact(s) time (year) and scenario.

\subsection{Disc Harrowing Fuel Consumption Dependence on Optimal Bio-Impact(s) Time (Year) and Scenario}

Comparing 2015 and 2017, fuel consumption from disc harrowing decreased in SC1, SC7, and SC8 and increased in SC2, SC3, and SC4. The lowest fuel consumption was in SC2 in 2015, in SC8 in 2016, and in SC4 and SC7 in 2017. Fuel consumption in terms of year and by scenario and year-scenario interaction was statistically significant $(p<0.01)$ (Figure 4 ).

After the subsequent research of the fuel consumption of soil tillage, the essential effect of bio-impact was determined in reducing 1 to $2 \mathrm{~L}$ of fuel per hour in the first year when the wheat was growing.

For two years, the biometric application identified the most effective reduction of subsequent soil cultivation fuel costs was by using the bacterial mixture under the SC8 scenario.

In general, in the third year, wheat rotation with rape had a major impact on fuel consumption, regardless of biological products. In addition, the effectiveness of biomeasurements was determined by a fuel consumption of up to $1 \mathrm{~L}$ compared to that of the control variant.

Summing up the percentage reduction in fuel consumption compared to that of the control variant, the maximum amount of noncultivated soil was set at $23 \%$ in the second year of the biometric application. 


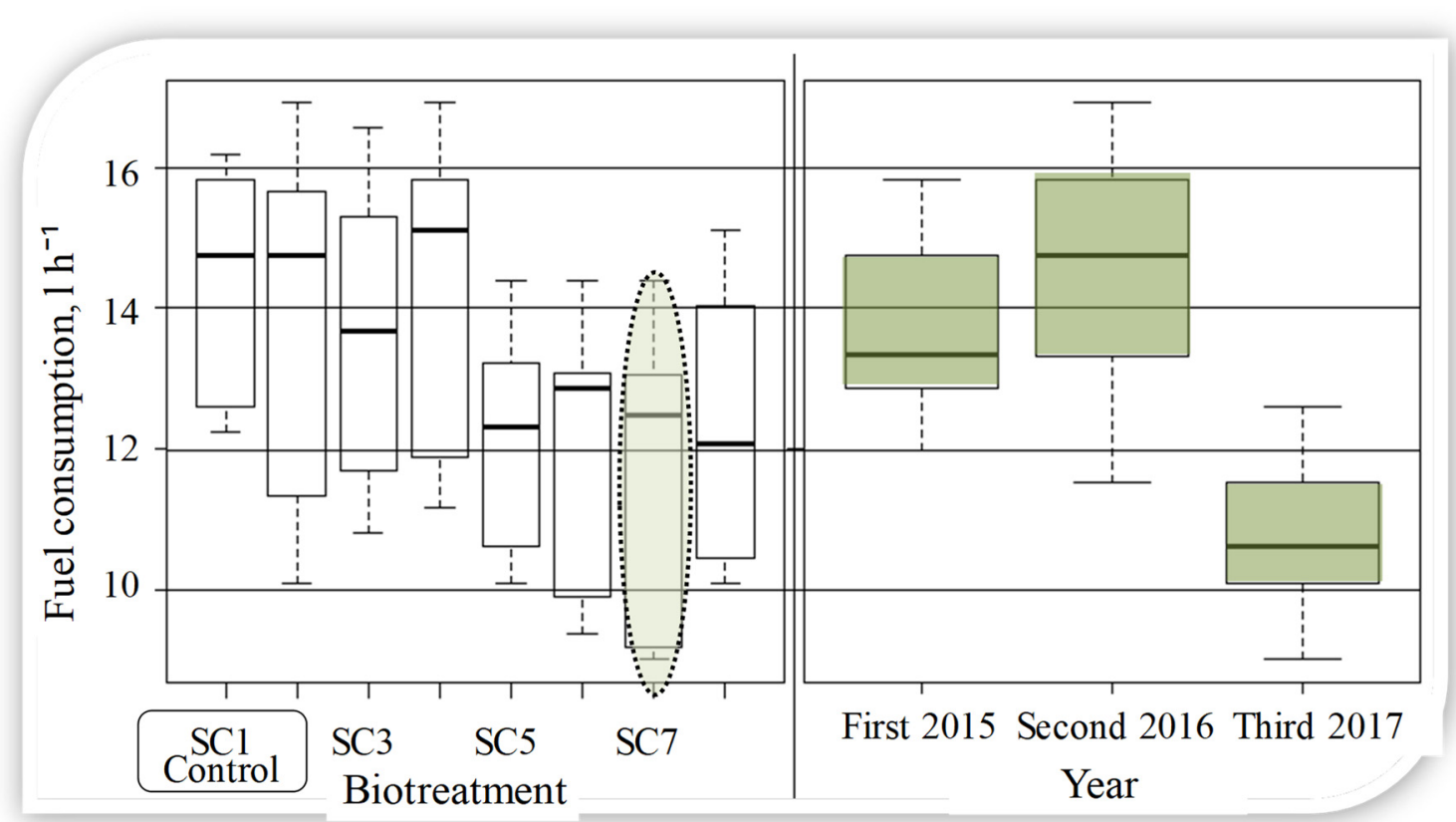

Figure 4. Disc harrowing fuel consumption $\left(\mathrm{L} \mathrm{h}^{-1}\right)$ dependence on bio-impact(s) time (year) and scenario.

\section{3. $\mathrm{CO}_{2}$ from Soil Dependence on Optimal Bio-Impact(s) Time (Year) and Scenario}

With the systematic reduction of carbon dioxide emissions from the soil accounted for on a monthly basis, the focus of the last 8 scenarios was Azotobacter chroococcum and Azospirillum brasilense bacteria, phosphorus, potassium, seaweed extract.

The average change in $\mathrm{CO}_{2}$ emissions from soil in 2015-2017 was an increase in all scenarios. The lowest $\mathrm{CO}_{2}$ value was set in SC1 in 2015, in SC4 in 2016, and in SC8 in 2017. $\mathrm{CO}_{2}$ emissions were statistically significant in terms of year, but according to the scenario, no differences were detected $(p<0.01)$. The smallest increase was in SC3 $\left(0.99 \mu \mathrm{mol} / \mathrm{m}^{2} / \mathrm{s}\right)$, and the largest increase was in SC4 $\left(7.76 \mu \mathrm{mol} \mathrm{m}^{-2} \mathrm{~s}^{-1}\right)$ (Figure 5).

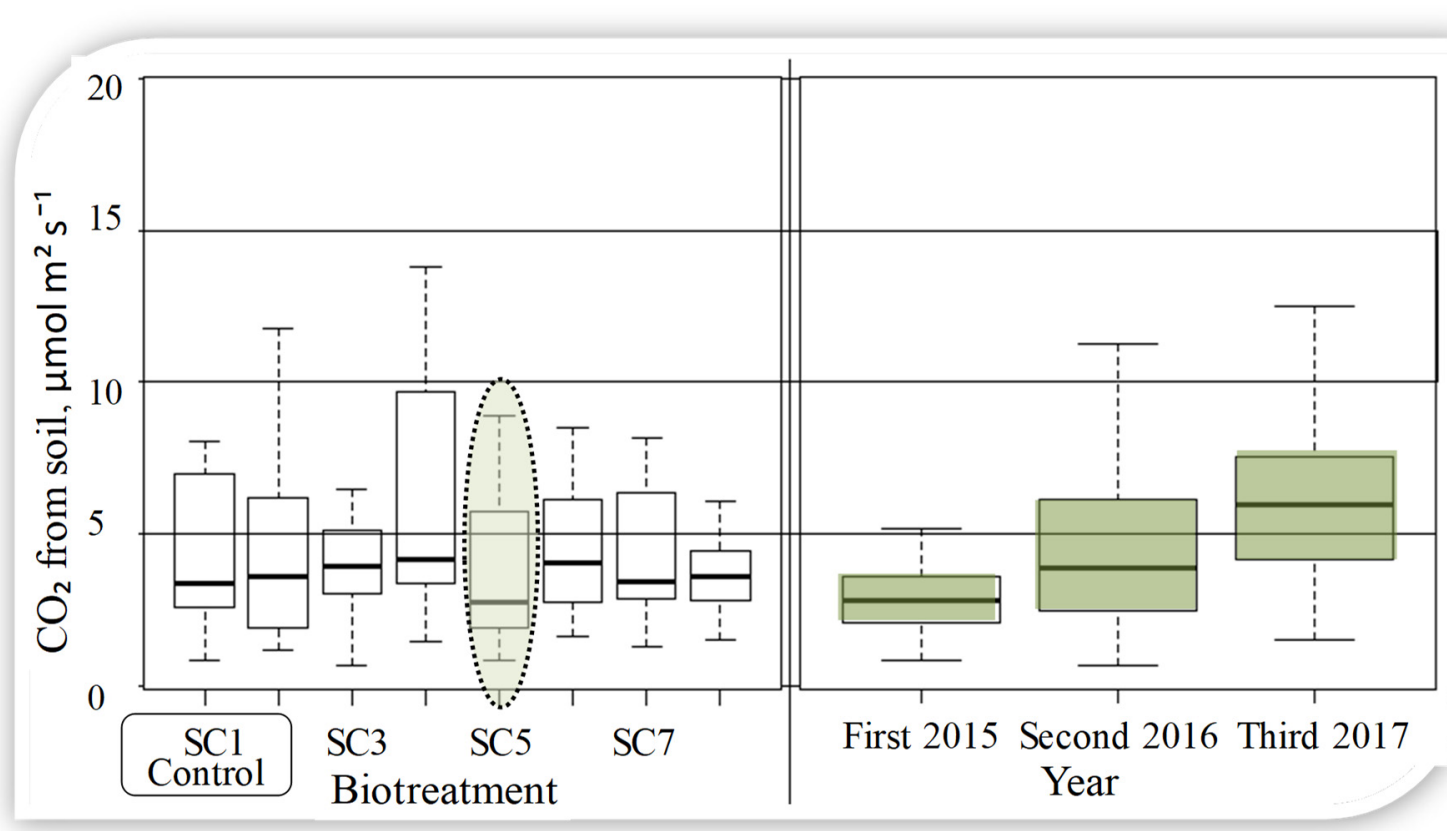

Figure 5. $\mathrm{CO}_{2}$ from soil $\left(\mu \mathrm{mol} \mathrm{m} \mathrm{m}^{2} \mathrm{~s}^{-1}\right)$ dependence on bio-impact(s) time (year) and scenario. 
3.4. Elected Soil Characteristics (Density, Total Porosity, Humus, Stability, Moisture) Dependence on Optimal Bio-Impact(s) Time (Year) and Scenario

Soil density reduced in all biotreatment scenarios, compared to control scenario SC1 through all years. The lowest density was set using SC6, SC7, SC8 scenarios growing wheat in the second year, and using $\mathrm{SC} 3$ growing rapeseed in the third year. The largest soil density decrease was observed in SC2 $\left(0.26 \mathrm{~g} \mathrm{~cm}^{-3}\right)$. After statistical analysis soil density had significant differences between first, second and third research year, but had no significant differences between most of scenarios $(p<0.01)$.

Due to the regularity of the bio-impact on the soil properties, soil-specific properties were identified that had a significant effect on fuel consumption changes. Soil density could be reduced to $13 \%$ using bio-impact (Figure 6).

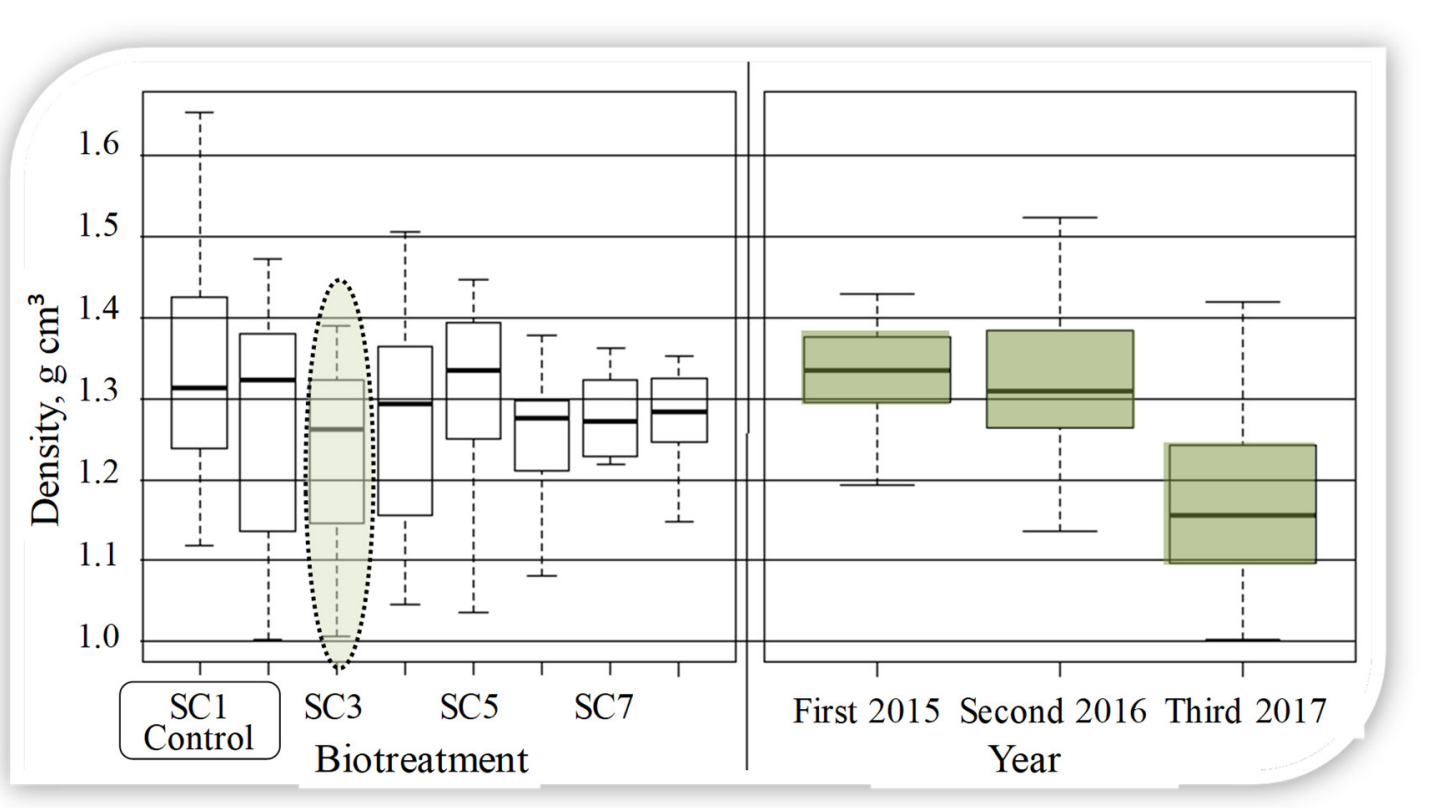

Figure 6. Soil density $\left(\mathrm{g} \mathrm{cm}^{-3}\right)$ dependence on bio-impact(s) time (year) and scenario.

Bio-impact was also effective for total soil porosity, with a significant increase of up to $25 \%$, which had a significant effect on fuel consumption with changes in land use.

The total porosity mean change over 2015-2017, compared to that in 2015 and 2017, showed an increase in all scenarios. The maximum value for total porosity was set for SC7 in 2015, for SC8 in 2016, and for SC3 in 2017. Total pore size was statistically significant $(p<0.001)$ both in terms of year $(p<0.001)$ and scenario. The largest increase was in SC5 $(9.60 \%)$ (Figure 7 ).

The humus average change over 2015-2017, compared with that in 2015 and 2017, only showed an increase in SC2 (0.15). The highest value of humus was in SC6 in 2015, in SC7 in 2016, and in SC1 in 2017. Humus values differed significantly by year $(p<0.000)$, and the differences among the scenarios were not significant. The largest decrease was observed in SC6 (1.95\%) (Figure 8). 


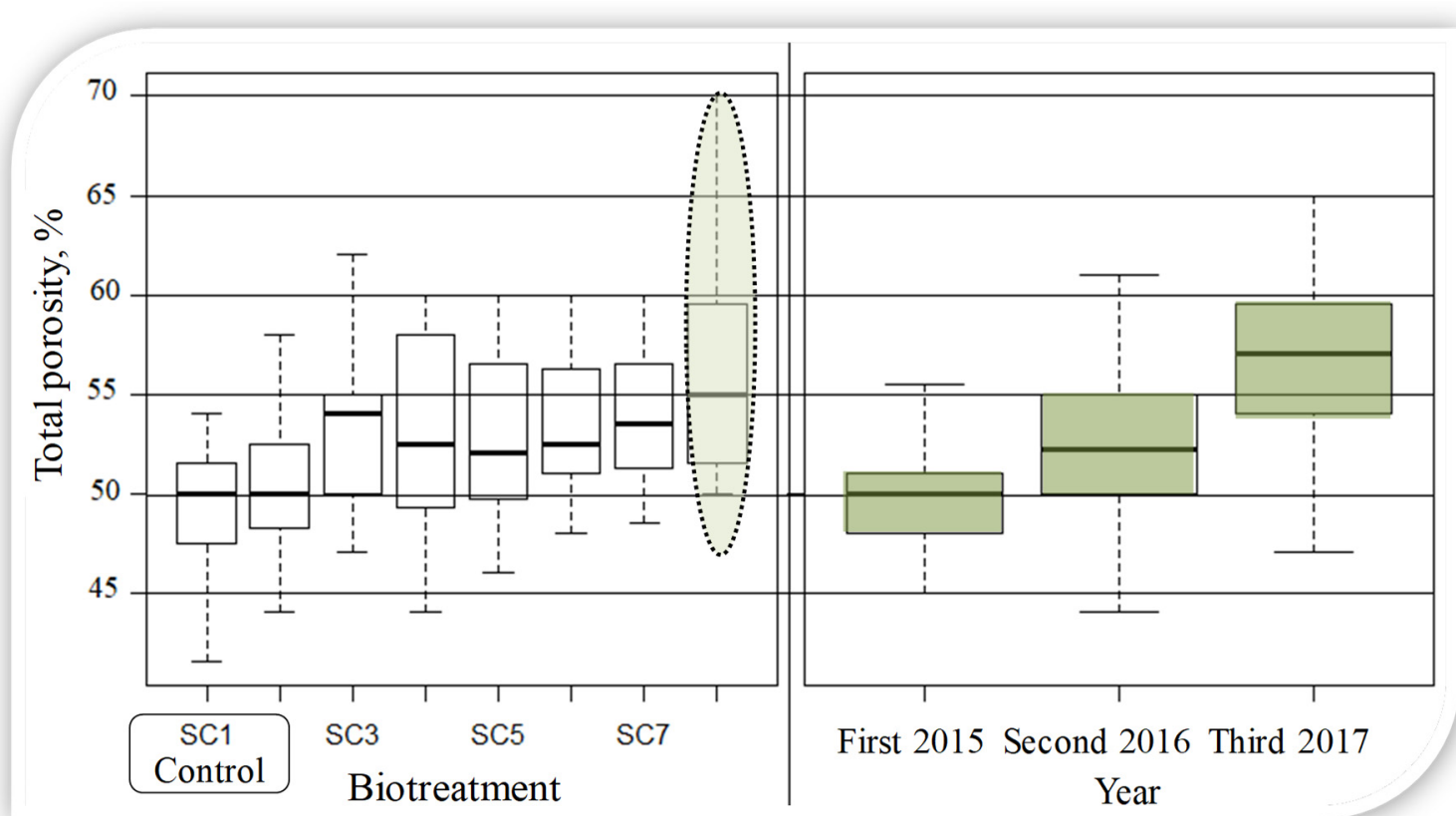

Figure 7. Total porosity of soil (\%) dependence on bio-impact time (year) and scenario.

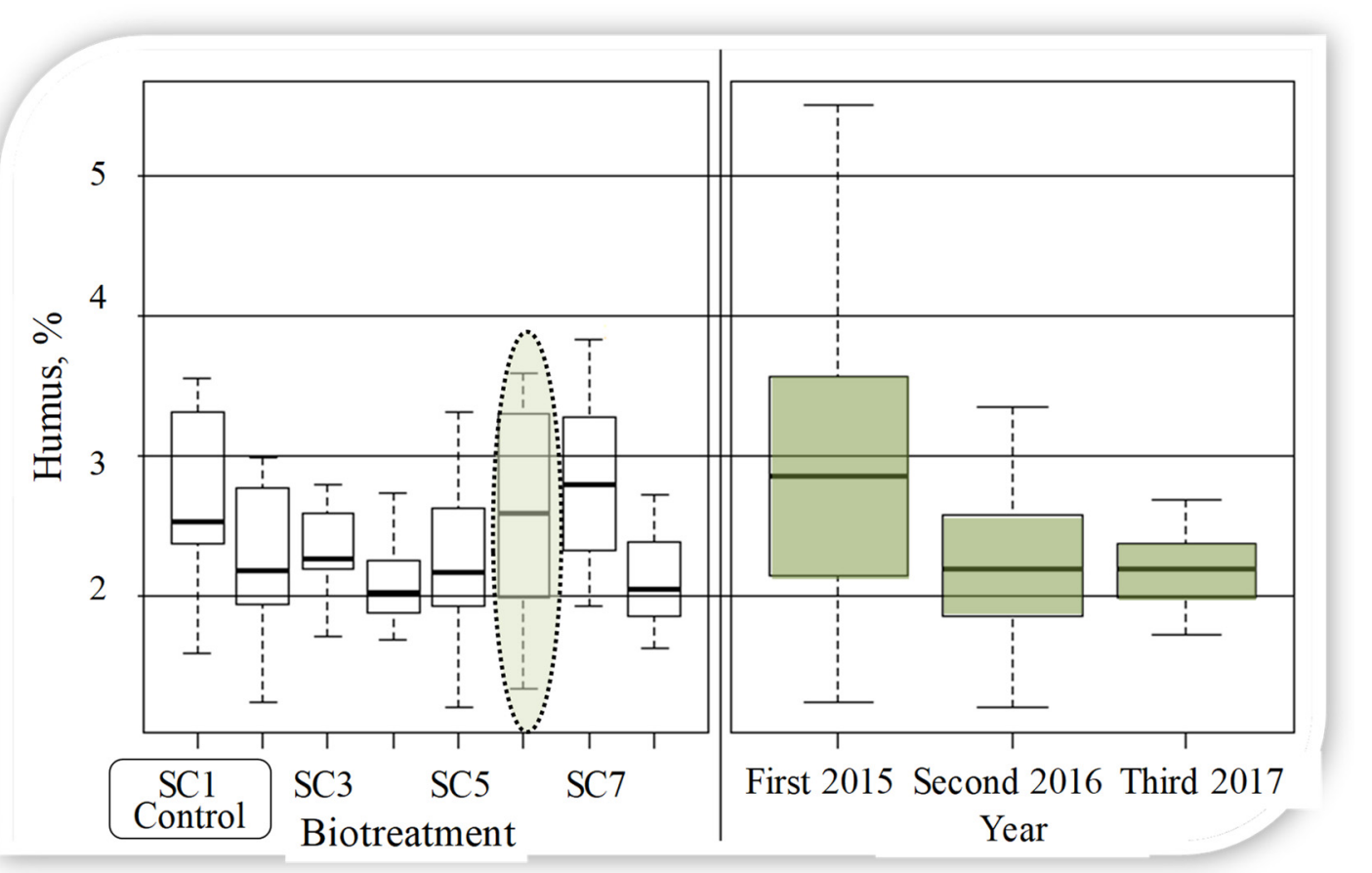

Figure 8. Humus (\%) dependence on bio-impact(s) time (year) and scenario.

Stability averages for 2015-2017 decreased, compared to those in 2015 and 2017. The highest value of stability was observed in SC6 all year. Stability values differed significantly (both by year and by scenario) $(p<0.01)$ and were significantly different from year-to-year for scenario. The largest decrease was in SC4 (15.40\%), with the lowest in SC3 (5.13) (Figure 9). 


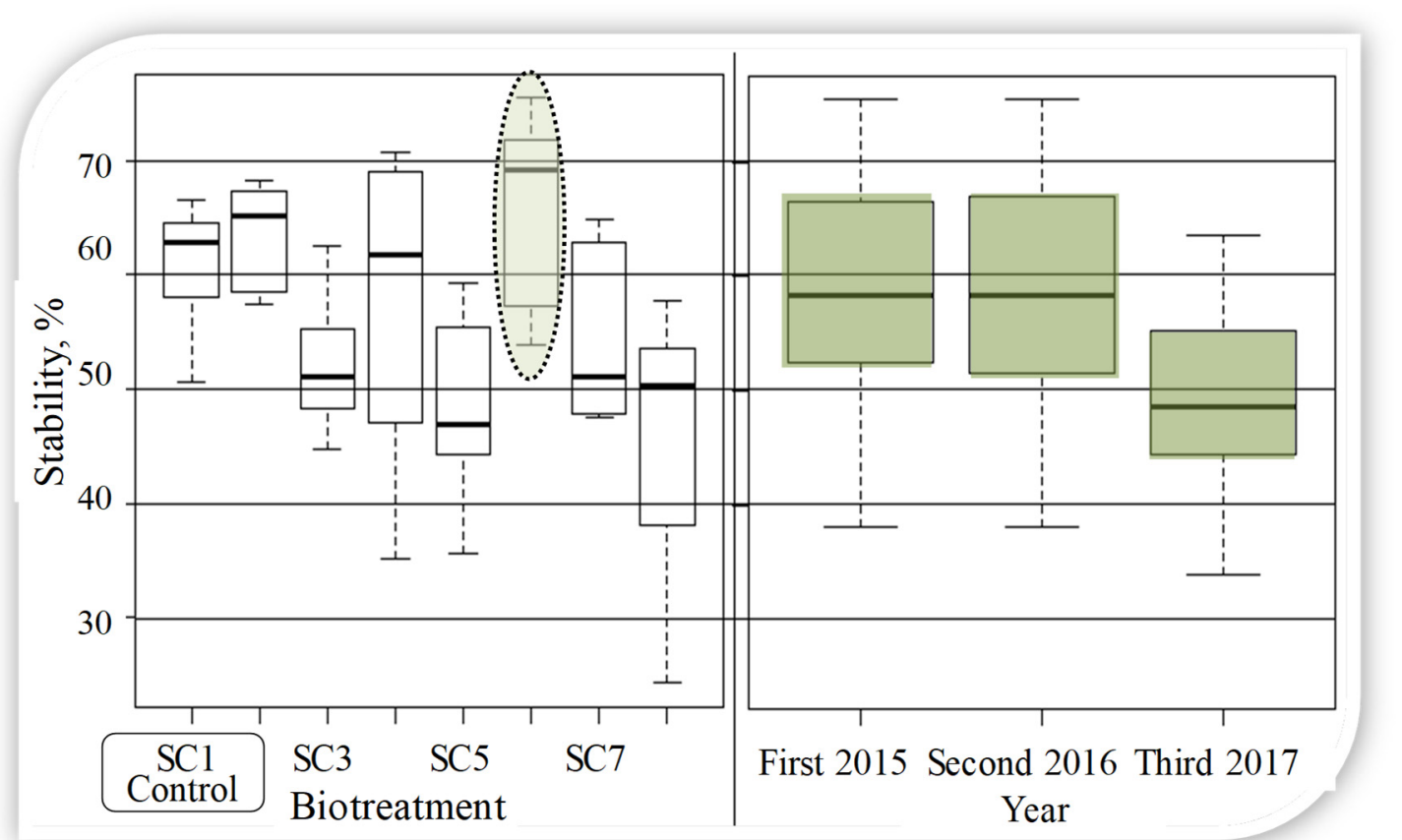

Figure 9. Stability (\%) dependence on bio-impact(s) time (year) and scenario.

The change in soil moisture content mean values for 2015-2017 showed a decrease only in SC8, compared with that in 2015 and 2017. The highest soil moisture content value was set for SC6 in 2015, for SC7 in 2016, and for SC1 in 2017. Soil moisture content values differed significantly $(p<0.01)$ both in terms of year and by scenario, and significant differences were observed in the year-scenario interaction. The smallest difference from the optimal value (20) was in SC6 in 2016 (Figure 10).

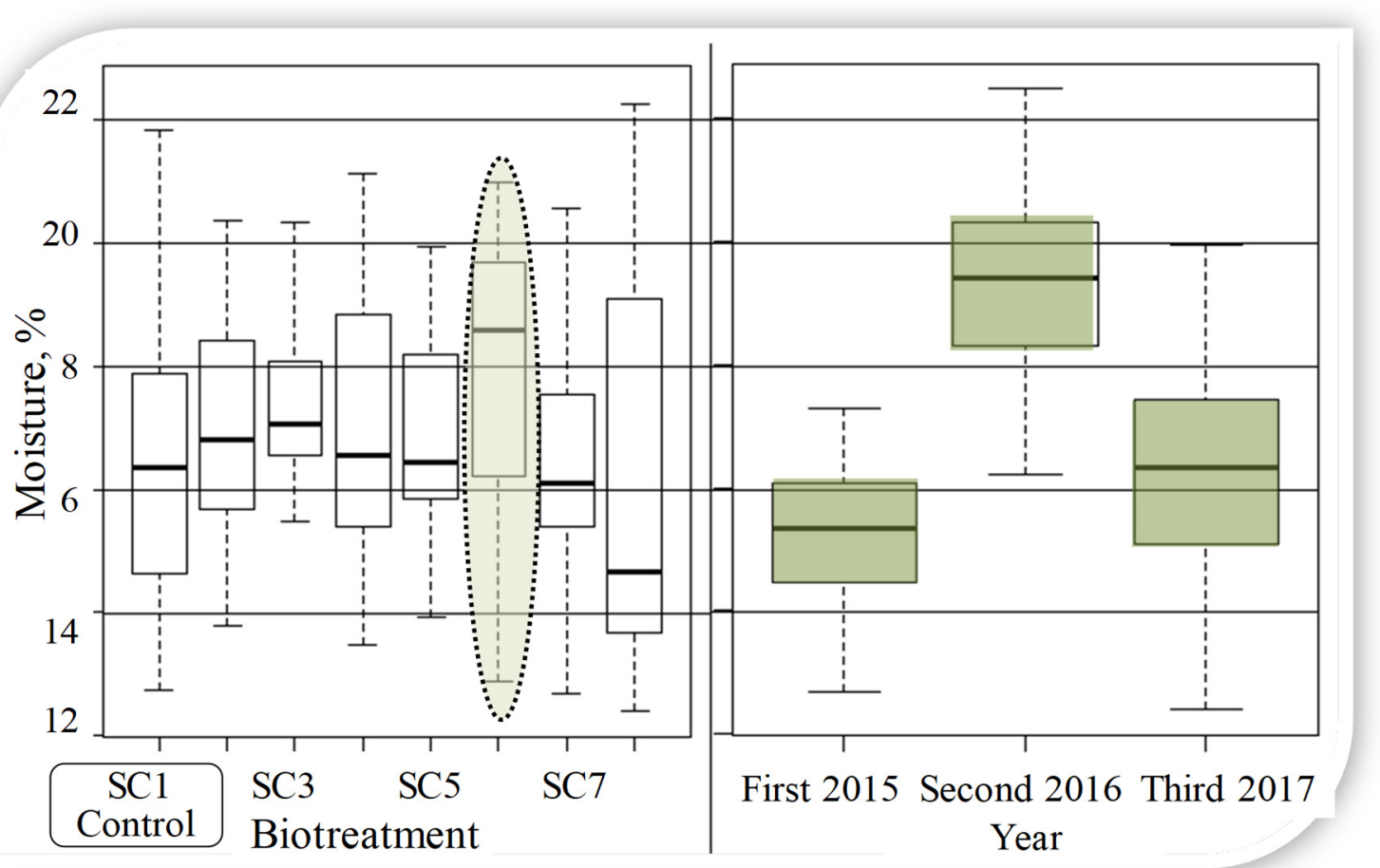

Figure 10. Soil moisture content (\%) dependence on bio-impact(s) time (year) and scenario. 


\subsection{Multicriteria Evaluation of the Optimal Bio-Impact Effectiveness for Environmental Sustainability}

The best combination was difficult to find based on the generic main indicator analysis; therefore, a multicriteria assessment was performed according to the methodology described in Section 2.

First, the weight of the criteria was determined, and all criteria were grouped into 3 categories as follows:

(1) Ploughing fuel consumption $\left(\mathrm{L} \mathrm{h}^{-1}\right)$, disc harrowing fuel consumption $\left(\mathrm{L} \mathrm{h}^{-1}\right)$, and yield $\left(\mathrm{t} \mathrm{ha}^{-1}\right)$;

(2) $\mathrm{CO}_{2}$ from soil $\left(\mu \mathrm{mol} \mathrm{m} \mathrm{m}^{-1}\right)$ and soil density $\left(\mathrm{g} \mathrm{cm}^{3}\right)$ and total porosity $(\%)$;

(3) Soil humus (\%), soil stability (\%), and soil moisture content (\%).

The importance of criteria in the same group was equal. According to the choices, the pairwise comparison matrix was constructed (Table 3).

The comparison matrix was normalized using formulas, and the criteria weight vector $\mathrm{W}$ was built (Table 4 ).

Table 3. Pairwise comparison matrix. $\mathrm{C} 1$ - ploughing fuel consumption, $\mathrm{C} 2$ - disc harrowing fuel consumption, $\mathrm{C} 3-\mathrm{yield}, \mathrm{C} 4-\mathrm{CO} 2$ from soil, C5-soil density, C6-yotal porosity, C7-humus, C8-stability, and C9-moisture.

\begin{tabular}{|c|c|c|c|c|c|c|c|c|c|}
\hline Criteria Weight & 0.1905 & 0.1905 & 0.1905 & 0.0952 & 0.0952 & 0.0952 & 0.0476 & 0.0476 & 0.0476 \\
\hline Indicator & C1 & C2 & C3 & $\mathrm{C} 4$ & $\mathrm{C} 5$ & C6 & C7 & C8 & C9 \\
\hline $\mathrm{C} 1$ & 1 & 1 & 1 & 2 & 2 & 2 & 4 & 4 & 4 \\
\hline $\mathrm{C} 2$ & 1 & 1 & 1 & 2 & 2 & 2 & 4 & 4 & 4 \\
\hline $\mathrm{C} 3$ & 1 & 1 & 1 & 2 & 2 & 2 & 4 & 4 & 4 \\
\hline $\mathrm{C} 4$ & 0.5 & 0.5 & 0.5 & 1 & 1 & 1 & 2 & 2 & 2 \\
\hline C5 & 0.5 & 0.5 & 0.5 & 1 & 1 & 1 & 2 & 2 & 2 \\
\hline C6 & 0.5 & 0.5 & 0.5 & 1 & 1 & 1 & 2 & 2 & 2 \\
\hline $\mathrm{C} 7$ & 0.25 & 0.25 & 0.25 & 0.5 & 0.5 & 0.5 & 1 & 1 & 1 \\
\hline $\mathrm{C} 8$ & 0.25 & 0.25 & 0.25 & 0.5 & 0.5 & 0.5 & 1 & 1 & 1 \\
\hline C9 & 0.25 & 0.25 & 0.25 & 0.5 & 0.5 & 0.5 & 1 & 1 & 1 \\
\hline
\end{tabular}

Since the purpose of the assessment was different (maximization, minimization, optimum), some of the indicator values were transformed, such as fuel consumption, $\mathrm{CO}_{2}$ from soil, and density, by applying formulas. All measured values of the indicators were transformed into unitless values using the SAW method with the data obtained during the study, a multicriteria assessment of the individual year was performed, and the results of that year were summarised (Figures 11 and 12).

Table 4. Multicriteria assessment of the best scenario.

\begin{tabular}{c|cccc}
\hline 2015 & 1 & & & \\
2016 & -0.39 & 1 & 1 & \\
2017 & 0.68 & -0.43 & 0.76 & Total \\
Total & 0.59 & -0.04 & 2017 & 8 \\
& 2015 & 2016 & 7 & 7 \\
SC1 & 3 & 5 & 6 & 5 \\
SC2 & 5 & 3 & 3 & 6 \\
SC3 & 7 & 8 & 8 & 4 \\
SC4 & 8 & 2 & 5 & 1 \\
SC5 & 4 & 7 & 1 & 3 \\
SC6 & 1 & 4 & 2 & 2 \\
SC7 & 2 & 6 & 4 & \\
SC8 & 6 & 1 & & \\
\hline
\end{tabular}

The correlation coefficients were calculated and showed that the estimates for 2016 were different (from 2015 to 2016, $r=-0.39$; from 2016 to 2017, $r=-0.43$ ); however, the correlation coefficient was $r=0.68$ for 2015 and 2017. The overall assessment best correlated 
with the 2017 assessment. The most suitable end/alternative for the discussed areas was determined.

$$
-\mathrm{S} 1-\mathrm{S} 2-\mathrm{S} 3-\mathrm{S} 4-\mathrm{S} 5-\mathrm{S} 6-\mathrm{S} 7-\mathrm{S} 8
$$

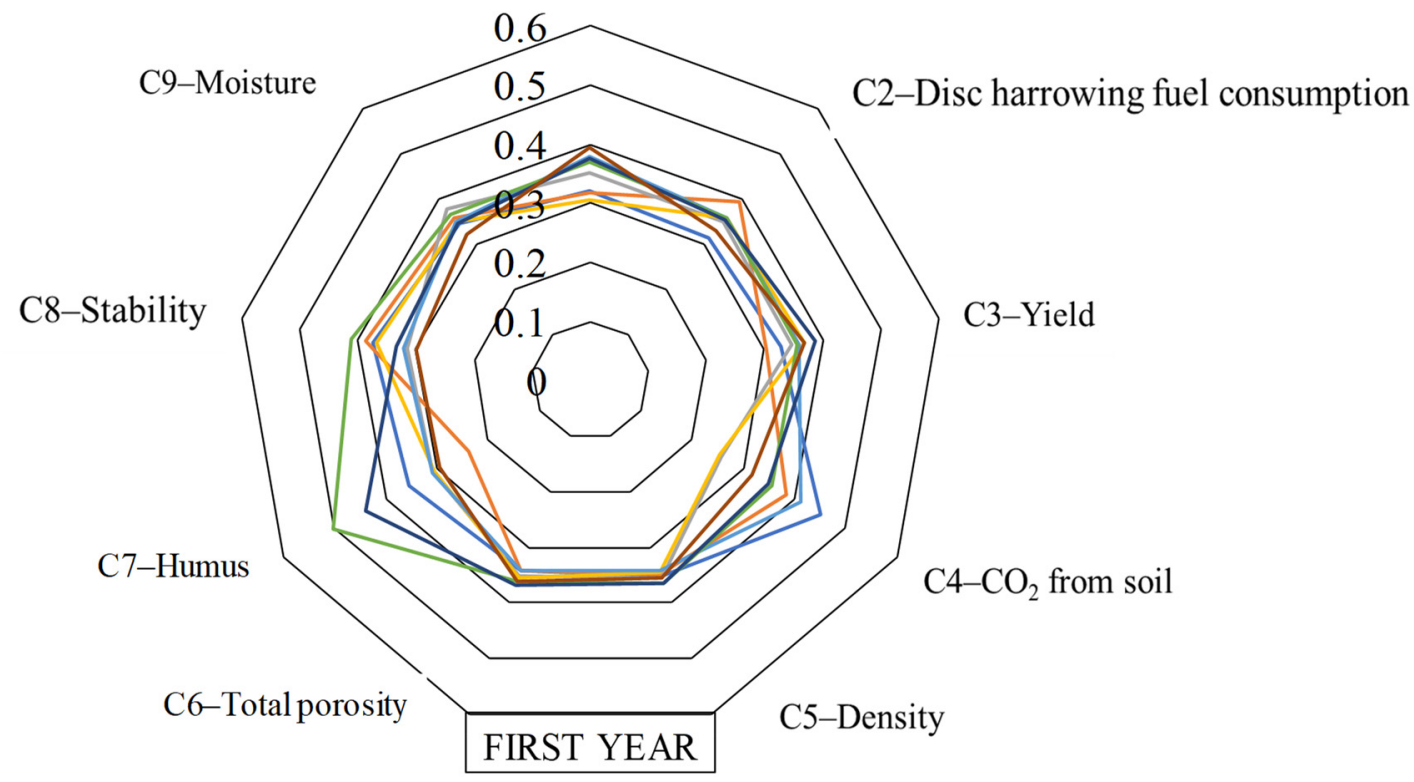$$
-\mathrm{S} 1-\mathrm{S} 2-\mathrm{S} 3-\mathrm{S} 4-\mathrm{S} 5-\mathrm{S} 6-\mathrm{S} 7-\mathrm{S} 8
$$

C1-Ploughing fuel consumption

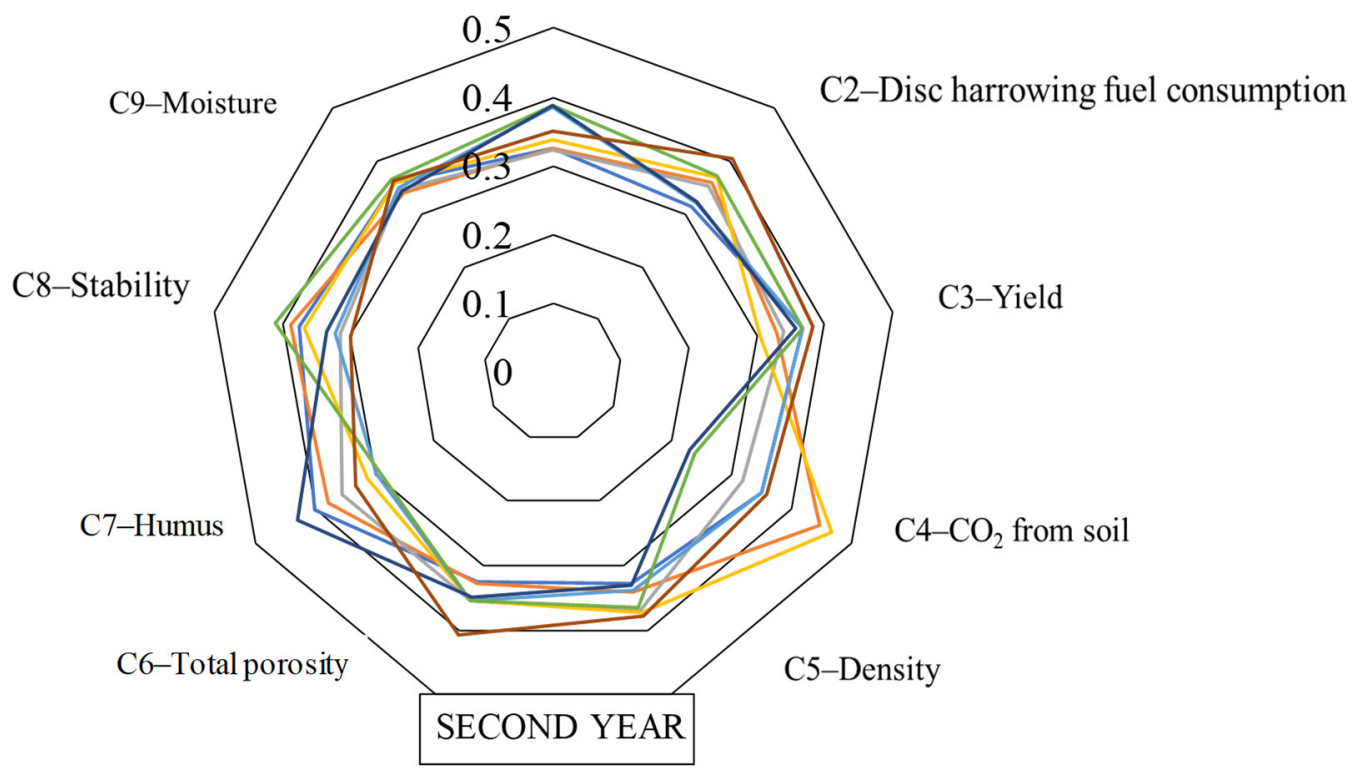

Figure 11. Cont. 


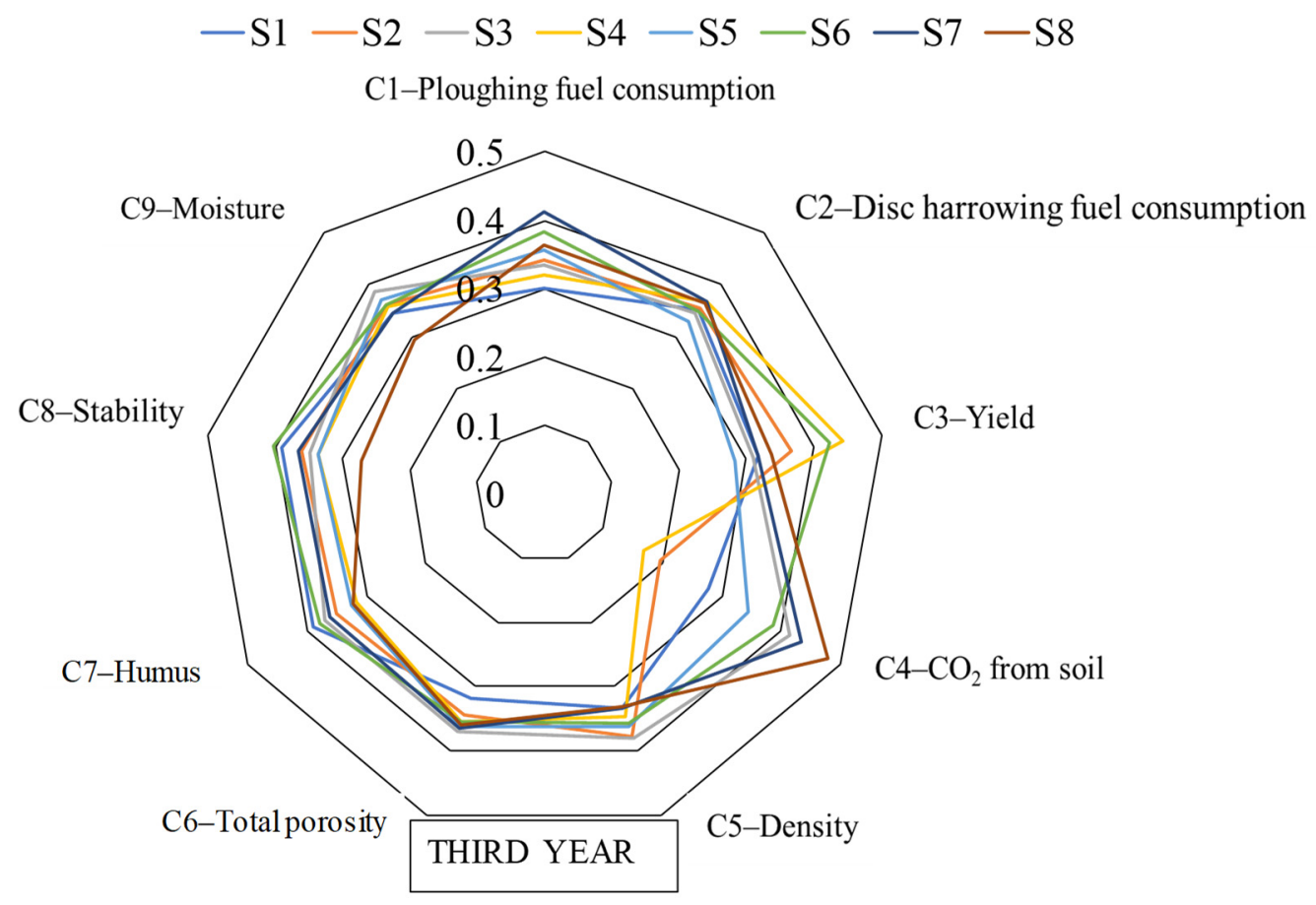

Figure 11. Multicriteria evaluation of the bio-impact effectiveness.

For the purposes, the SAW method using the data obtained during the investigation was carried out by the various multiyear and summarizing the results of the year.

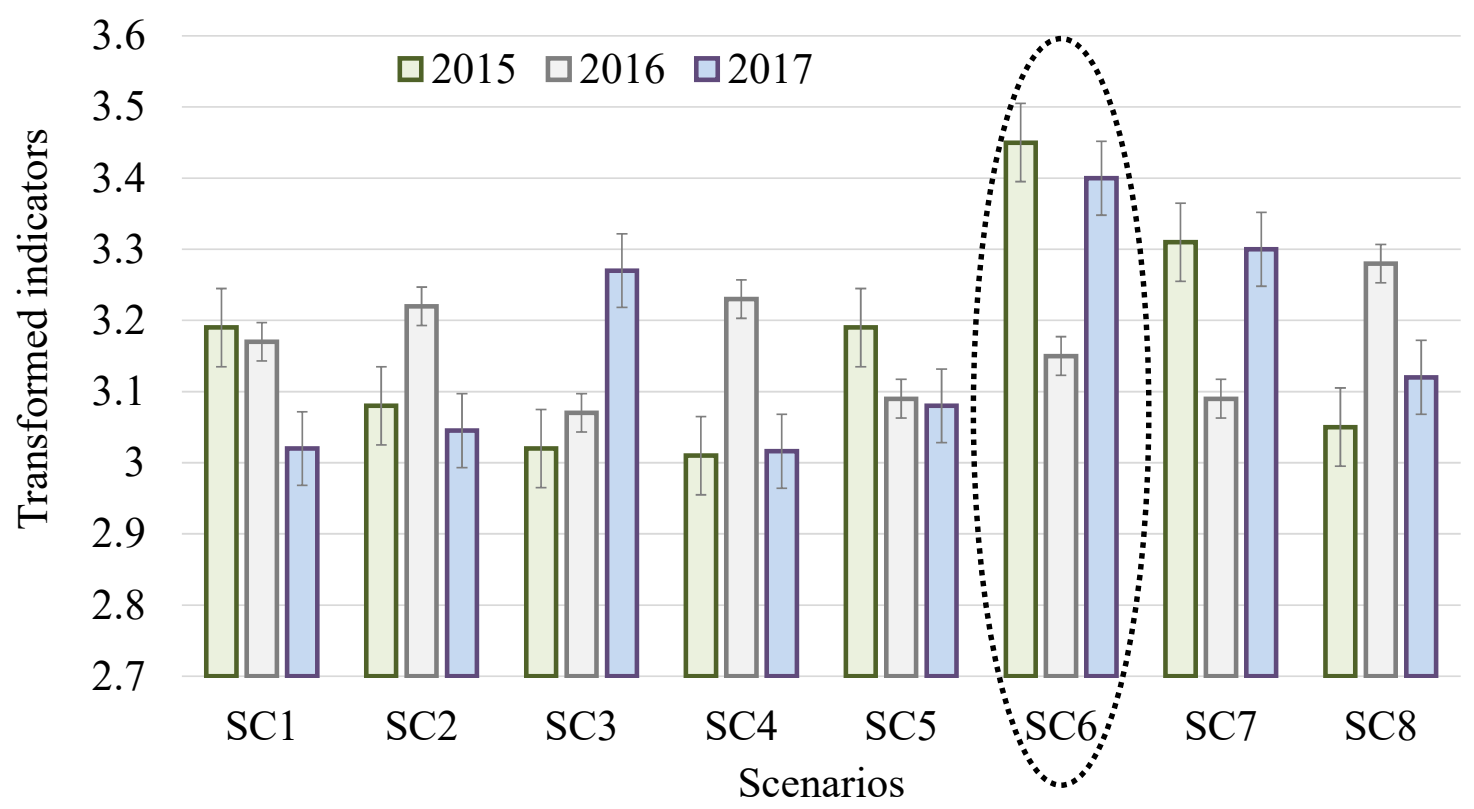

Figure 12. Multicriteria evaluation of the bio-impact effectiveness.

The multicriteria assessment led to different scenarios for different years. Scenario rating data showed that SC6 was the best scenario in 2015 and 2017 and that SC8 was the best in 2016. In the joint assessment, SC6 (Figure 12) should be recognized as the best-case scenario.

After the multicriteria ( $\mathrm{C} 1$ - ploughing fuel consumption, $\mathrm{C} 2$ - disc harrowing fuel consumption, C3-yield, C4-CO2 from soil, C5-density, C6-total porosity, C7-humus, C8-stability, and C9-moisture) joint evaluation by scenario, rating data using the Simple 
Additive Weighing mathematical method assessed SC6 as the best-case scenario, with the multicriteria effectiveness mostly highlighted after first (2015) and third (2017) soil treatments of bio-impacts (consisting of Essential oils of plants, 40 species of various herbs extracts, Marine algae extracts, Mineral oils, Azospirillum sp. (N)_bacterial colony count-1 $1 \times 10^{9} / \mathrm{mL}$, Frateuria aurentia $(K)$ bacterial colony count-1 $\times 10^{9} / \mathrm{mL}$, Bacillus megaterium $(P)$ _bacterial colony count $-1 \times 10^{9} / \mathrm{mL}$, Seaweed extract $-10 \%$ by volume).

The better environmental sustainability results in crop production were achieved using bio-impact by SC6 scenario-spraying a bio-solution consisting of Azotobacter vinelandii, humic acids, gibberellic acid, copper, zinc, manganese, iron, calcium, and sodium molybdate in the spring. It achieved the best soil bio-impact effectiveness-less energy consumption from ploughing and disc harrowing operations, parallelly less harmful emissions from agricultural machinery, less $\mathrm{CO}_{2}$ from soil, soil density, higher soil total porosity, soil humus, soil stability, yield and optimal soil moisture.

Other scientists identified that active development of bio-methods resulted in continuously increasing numbers of all technological processes implemented using microorganisms. Application of bio-fertilizers increased plant growth from normal [36], root development and growth have a direct and close connection with $\mathrm{P}$ and $\mathrm{N}$ uptake from soil [37]. It was also established the influence of enriched liquid organic fertilizers on the growth and nutrient uptake of maize under drought conditions in calcareous soil [38,39]. Dahm, Khattab, Banerjee, Condor, Peltrea, Montemurro and other researchers also found similar biotechnological effects on the productivity of crops, improving the microbiological state of the soil, and changing the physical and chemical properties of the soil. Soil treatment using biopreparations with nutrients $(\mathrm{N}, \mathrm{P}$, and $\mathrm{K}$ ) increased the organic carbon content of the soil and influenced the soil structure and porosity. Scientific results showed that biocrusts significantly improved soil physicochemical properties, basal respiration and soil alkaline phosphatase, protease, cellulose, and decreased $\mathrm{CO}_{2}$ in vegetated areas [40].

Plant biotechnology is a necessary tool to improve agriculture by increasing food production through tissue culture, molecular biology and crop improvement. One of the solutions to agricultural problems (soil degradation, salinity, heavy metal and hydrocarbon pollution, drought, desertification, deforestation, etc.) is biotechnology. Possible solutions using a sustainable model, the application of biotechnology in faster plant propagation, embryo plasma conservation and genetic improvement. The contribution of modern biotechnology to sustainability in agriculture is demonstrated by the genus Lupinus, which includes species useful for sustainable agriculture that are a source of protein and secondary metabolites, as well as crop rotation [41]. The influence of Bacillus subtilis strains and chitosan complexes on the productivity of common wheat and their infection with pathogens was determined after the development of preparative forms of multifunctional biopreparations. Studies have shown the effectiveness of polyfunctional preparations, together with strains of microorganisms as pathogen antagonists, and chitosan as an activator of plant disease resistance in protecting wheat from root rot, increasing yield and improving grain quality, best adapted to agri-ecological environmental factors [42]. In modern agricultural production, the application of innovative technologies has been evaluated as the physicochemical properties of nanoparticles contribute to biocompatibility and biological activity by interaction with wheat and other crops. Superoxide dismutase and catalase activity in crops decreased significantly at maximal morphophysiological parameters and increased sharply at concentrations corresponding to greater than $100 \mathrm{~g} / \mathrm{t}$ and $10 \mathrm{~g} / \mathrm{t}$ for nanoparticles between 35 and $60 \mathrm{~nm}$ and up to $20 \mathrm{~nm}$. The stability limit of 35-60 nm nanoparticles was much higher than the concentration of $100 \mathrm{~g} / \mathrm{t}$ nanoparticles, and up to $20 \mathrm{~nm}-0.001-10 \mathrm{~g} / \mathrm{t}$. The content of the hormone indole acetic acid was increased by exposure to nanoparticles, which increased the energy efficiency of plant respiration, the activity of enzymatic reactions, and the quality of wheat yields and grains by enhancing seedling viability while minimizing weed exposure [43]. The main trend in modern crop production is the expansion of the use of plant protection solutions and technologies, ensuring not only the effective management of pest populations, but also the production of 
environmentally friendly agricultural products with a minimal anthropogenic impact on agriculture. Established complexes of biopreparations containing B. subtilis strains and chitosan have a common biological activity, which is manifested by optimization of the physiological condition of wheat plants, increasing productivity and disease resistance [44].

\section{Conclusions}

1. After carried out three year scientific researches of disc harrowing, ploughing, harvest and soil properties parameters were identified that soil biotreatments in agricultural practices could be oriented towards a reduction in fuel consumption, followed by reductions in $\mathrm{CO}_{2}$ emissions from machinery, dynamics of soil composition, properties and yield.

2. Conducted multicriteria assessment can be oriented towards for farmers as new opportunity to choose one optimal decision and consolidation of distinct experimental researches of soil bio-impact effects in agriculture and summarise wide coverage investigations of various aspects.

3. According to multicriteria assessment using the Simple Additive Weighing mathematical method discovered one bio-impact for maximization values of yield, total porosity, humus, stability; minimization of ploughing and disc harrowing fuel consumption, density, $\mathrm{CO}_{2}$ emission; optimization of soil moisture content indicators.

4. After the multicriteria evaluation of main criteria based on scenario ratings, the data highlighted the most effective bio-impact scenario after the first and third soil treatments, which consisted of essential oils of plants, 40 species of various herbs extracts, Marine algae extracts, Mineral oils, Azospirillum sp. (N), Frateuria aurentia (K), Bacillus megaterium (P), Seaweed extract.

Author Contributions: Conceptualization, E.Š.; Data curation, V.N. and D.R.; Investigation, V.N. and E. Š.; Methodology, D.R.; Software, D.R.; Visualization, V.N.; Writing—original draft, E.Š. All authors have read and agreed to the published version of the manuscript.

Funding: This research received no external funding.

Conflicts of Interest: The authors declare no conflict of interest.

\section{References}

1. Khattab, R.Y.; Arntfield, S.D.; Nyachoti, C.M. Nutritional quality of legume seeds as affected by some physical treatments, Part 1 : Protein quality evaluation. LWT-Food Sci. Technol. 2009, 42, 1107-1112. [CrossRef]

2. Banerjee, D. Endophytic fungal diversity in tropical and subtropical plants. Res. J. Microbiol. 2011, 6, 54-62. [CrossRef]

3. Jakienè, E. Effect of biological products on sugar-beet crop. Agricultural sciences. Effects of organic products on sugar beet crops. Agric. Sci. 2011, 18, 64-71.

4. Vaitauskienè, K.; Šarauskis, E.; Naujokienè, V.; Liakas, V. The influence of free-living nitrogen-fixing bacteria on the mechanical characteristics of different plant residues under no-till and strip-till conditions. In Soil and Tillage Research; Elsevier: Amsterdam, The Netherlands, 2015; Volume 154, pp. 91-102.

5. Blaszczyk, L.; Siwulski, M.; Sobieralski, K.; Lisiecka, J.; Jedryczka, M. Trichoderma spp.-Application and prospects for use in organic farming and industry. J. Plant Prot. Res. 2014, 54, 309-317. [CrossRef]

6. Atanasova, L.; Crom, S.; Gruber, S.; Coulpier, F.; Seidl-Seiboth, V.; Kubicek, C.; Druzhinina, I.S. Comparative transcriptomics reveals different strategies of Trichodermamycoparasitism. BMC Genom. 2013, 14, 121. [CrossRef]

7. Oskiera, M.; Szczecha, M.; Stępowska, A.; Smolińska, U.; Bartoszewskic, G. Monitoring of Trichoderma species in agricultural soil in response to application of biopreparations. Biol. Control 2017, 113, 65-72. [CrossRef]

8. Santos, C.A.; Caldeira, M.L.; Lopes da Silva, T.; Novais, J.M.; Reis, A. Enhanced lipidic algae biomass production using gas transfer from a fermentative Rhodosporidium toruloides culture to an autotrophic Chlorella protothecoides culture. Bioresour. Technol. 2013, 138, 48-54. [CrossRef]

9. Chachina, S.B.; Voronkova, N.A.; Baklanova, O.N. Biological Remediation of the Petroleum and Diesel Contaminated Soil with Earthworms Eisenia Fetida. Procedia Eng. 2016, 152, 122-133. [CrossRef]

10. Sathiyabama, M.; Parthasarathy, R. Biological preparation of chitosan nanoparticles and its in vitro antifungal efficacy against some phytopathogenic fungi. Carbohydr. Polym. 2016, 151, 321-325. [CrossRef]

11. Liu, Y.; Xing, Z.; Yang, H. Effect of biological soil crusts on microbial activity in soils of the Tengger Desert (China). J. Arid. Environ. 2017, 144, 201-211. [CrossRef] 
12. Montemurro, F.; Ferri, D.; Tittarelli, F.; Canali, S.; Vitti, C. Anaerobic Digestate and On-Farm Compost Application: Effects on Lettuce (Lactuca sativa L.) Crop Production and Soil Properties. Compost Sci. Util. 2010, 18, 184-193. [CrossRef]

13. Kieliszek, M.; Kot, A.M.; Bzducha-Wróbel, A.; Błażejak, S.; Gientka, I.; Kurcz, A. Biotechnological use of Candida yeasts in the food industry: A review. Fungal Biol. Rev. 2017, 31, 185-198. [CrossRef]

14. Cabala, P. Using the analytic hierarchy process in evaluating decision alternatives. In Operations Research and Decisions; Wroclaw University of Technology: Wroclaw, Poland, 2010; Volume 1, pp. 1-23.

15. Bystrzanowska, M.; Tobiszewski, M. How can analysts use multicriteria decision analysis? Trends Anal. Chem. 2018, 105, 98-105. [CrossRef]

16. Niyigena, C.; Amziane, S.; Chateauneuf, A. Multicriteria analysis demonstrating the impact of shiv on the properties of hemp concrete. Constr. Build. Mater. 2018, 160, 211-222. [CrossRef]

17. Skafa, L.; Buonocorea, E.; Dumonteta, S.; Capone, R.; Franzesea, P.P. Food security and sustainable agriculture in Lebanon: An environmental accounting framework. J. Clean. Prod. 2018, 209, 1025-1032. [CrossRef]

18. Uitto, A.; Saloranta, S. Subject Teachers as Educators for Sustainability: A Survey Study. Educ. Sci. 2017, 7, 8. [CrossRef]

19. Zervaa, A.; Tsantopoulos, G.; Grigoroudis, E.; Arabatzisa, G. Perceived citizens' satisfaction with climate change stakeholders using a multicriteria decision analysis approach. Environ. Sci. Policy 2018, 82, 60-70. [CrossRef]

20. Kirppua, H.; Lahdelma, R.; Salminend, P. Multicriteria evaluation of carbon-neutral heat-only production technologies for district heating. Appl. Therm. Eng. 2018, 130, 466-476. [CrossRef]

21. Houshyar, E.; Grundmann, P. Environmental impacts of energy use in wheat tillage systems: A comparative life cycle assessment (LCA) study in Iran. Energy 2017, 122, 11-24. [CrossRef]

22. Kole, C. Cereals and Millets; Springer: Berlin/Heidelberg, Germany, 2015.

23. MAJ. Ministry of Jihad-e-Agriculture of Iran. Annual Agricultural Statistics. Available online: www.maj.ir (accessed on 1 December 2020).

24. Bystrzanowska, M.; Pena-Pereira, F.; Marcinkowski, L.; Tobiszewski, M. How green are ionic liquids?-A multicriteria decision analysis approach. Ecotoxicol. Environ. Saf. 2019, 174, 455-458. [CrossRef]

25. Naujokienè, V.; Šarauskis, E.; Lekavičienè, K.; Adamavičienė, A.; Buragienė, S.; Kriaučiūnienė, Z. The influence of biopreparations on the reduction of energy consumption and $\mathrm{CO}_{2}$ emissions in shallow and deep soil tillage. Sci. Total Environ. 2018, 626, 1402-1413. [CrossRef] [PubMed]

26. Saaty, T.L. Making and validating complex decisions with the ahp/anp. J. Syst. Sci. Syst. Eng. 2005, 14, 1-36. [CrossRef]

27. Aupetit, B.; Genest, C. On some useful properties of the Perron eigenvalue of a positive reciprocal matrix in the context of the analytic hierarchy process. Eur. J. Oper. Res. 1993, 70, 263-268. [CrossRef]

28. Hossain, M.F.; Adnan, Z.H.; Hasin, M.A.A. Improvement in weighting assignment process in Analytic Hierarchy Process by introducing suggestion matrix and Likert scale. Int. J. Supply Chain Manag. 2014, 3, 91-95.

29. De Feo, L.; Kieffer, J.; Smith, B. Towards Practical Key Exchange from Ordinary Isogeny Graphs. In ASIACRYPT 2018: Advances in Cryptology-ASIACRYPT 2018, Proceedings of the International Conference on the Theory and Application of Cryptology and Information Security, Brisbane, QLD, Australia, 2-6 December 2018; Springer: Cham, Germany, 2018; Volume 11274, pp. 365-394.

30. Mohammadi, S.J.; Sarmadian, F.; Jafarzadeh, A.A.; Ghorbani, M.A.; Shahbazi, F. Application of SAW, TOPSIS and fuzzy TOPSIS models in cultivation priority planning for maize, rapeseed and soybean crops. Geoderma 2018, 310, 178-190. [CrossRef]

31. Janssen, R. On the use of multi-criteria analysis in environmental impact assessment in The Netherlands. J. Multi-Criteria Decis. Anal. 2001, 10, 101-109. [CrossRef]

32. Podvezko, V. The Comparative analysis of MCDA methods SAW and COPRAS. Eng. Econ. 2011, 22, 134-146. [CrossRef]

33. Jovanovic, S.; Savic, S.; Jovicic, N.; Boskovic, G.; Djordjevic, Z. Using multi-criteria decision making for selection of the optimal strategy for municipal solid waste management. Waste Manag. Res. 2016, 34, 884-895. [CrossRef]

34. Podviezko, A.; Podvezko, V. Influence of Data Transformation on Multicriteria Evaluation Result. Procedia Eng. 2015, 122, 151-157. [CrossRef]

35. Vafaei, N.; Ribeiro, R.; Camarinha-Matos, L. Normalization Techniques for Multi-Criteria Decision Making: Analytical Hierarchy Process Case Study. In Doctoral Conference on Computing, Electrical and Industrial Systems; Springer: Cham, Germany, 2016; pp. 261-269. [CrossRef]

36. Obriot, F.; Stauffer, M.; Delaunay, Y.G.; Cheviron, N.; Peres, G. Multi-criteria indices to evaluate the effects of repeated organic amendment applications on soil and crop quality. Agric. Ecosyst. Environ. 2016, 232, 165-178. [CrossRef]

37. Chakraborty, S.; Yeh, C.H. A simulation based comparative study of normalization procedures in multiattribute decision making In AIKED'07 Proceedings of the 6th Conference on 6th WSEAS International Conference on Artificial Intelligence, Knowledge Engineering and Data Bases; WSEAS: Stevens Point, WI, USA, 2007; Volume 6, pp. 102-109.

38. Hoseini, R.; Mohammadi, E.; Kalatejari, S. Effect of bio-fertilizer on growth, development and nutrient content (leaf and soil) of Stevia rebaudiana Bertoni. J. Crop Prot. 2015, 4, 691-704.

39. Dogan, N.; Akinci, S.. Effects of water stress on the uptake of nutrients by bean seedlings (Phaseolus vulgaris L.). Fresenius Environ. Bull. 2011, 20, 2163-2170.

40. Moridi, A.; Zarei, M.; Moosavi, A.A.; Ronaghi, A. Influence of PGPR-enriched liquid organic fertilizers on the growth and nutrients uptake of maize under drought condition in calcareous soil. J. Plant Nutr. 2019, 42, 2745-2756. [CrossRef]

41. Álvarez, S.P.; Ardisana, E.F.H.; Leal, R.P. Plant Biotechnology for Agricultural Sustainability. In Resources Use Efficiency in Agriculture; Springer: Singapore, 2020; pp. 389-425. 
42. Novikova, I.; Popova, E.V.; Kolesnikov, L.E.; Priyatkin, N.S.; Kolesnikova, Y.R. Biological effectiveness of polyfunctional biopreparations in soft wheat cultivation and assessment of crop quality based on NDVI index. In BIO Web of Conferences; EDP Sciences: Les Ulis, France, 2020; Volume 18. [CrossRef]

43. Churilov, D.; Polischuk, S.; Churilov, G.; Shemyakin, A.; Churilova, V.; Andreev, K.; Arapov, I.; Obidina, I. The possibility of using biopreparations based on nanoparticles of biogenic metals in crop production and plant protection. In IOP Conference Series: Earth and Environmental Science, Proceedings of the International AgroScience Conference (AgroScience-2019), Cheboksary, Russia, 1-2 June 2019; IOP Publishing: Bristol, UK, 2019; Volume 433.

44. Kolesnikov, L.E.; Novikova, I.I.; Popova, E.V.; Priyatkin, N.S.; Zuev, E.V.; Kolesnikova, Y.u.R.; Solodyannikov, M.D. The effectiveness of biopreparations in soft wheat cultivation and the quality assessment of the grain by the digital X-ray imaging. Agron. Res. 2020, 18, 2436-2448. [CrossRef] 